\title{
Türkiye'de Sosyal Bilgiler Eğitiminin Yükseköğretimdeki Durumu
}

\author{
DOI: 10.26466/opus.545800 \\ *
}

\section{Erhan Yaylak*}

\author{
* Dr. Öğr. Üyesi, Ordu Üniversitesi, Eğitim Fakültesi, Merkez/Ordu/Türkiye
} E-Posta: erhanyaylak@gmail.com

ORCID:0000-0003-4612-3041

\section{Öz}

Türkiye'de üniversitelerin Ĕ̆itim Fakülteleri Sosyal Bilgiler Eğitimi Ana Bilim Dalını (SBEABD) çeşitli değişkenler açısından incelemesi amaçlanan bu araştırma, nitel araştırma yöntemlerinden durum çalışması (case study) yöntemi kapsamında yürütülmüştür. Araştırmanın kapsamını Türkiye'de bulunan devlet üniversiteleri oluşturmaktadır. Buradaki ölçüt, Eğitim Fakülteleri bünyesinde SBEABDolan devlet üniversiteleridir. Araştırma; 2019 yılı Ocak ve Şubat ayındaki veriler ile yapılmıştır. Araştırmanın verileri için Yüksek Öğretim Kurumu (YÖK) Akademik, YÖK Atlas, YÖK Tez Tarama ve üniversitelerin resmî web sayfalarından yararlanılmıştır. Veriler betimsel (tanımlayıcı) analiz yöntemi ile çözümlenmiş ve SPSS 25 paket programından yararlanılmıştır. Araştırmanın sonuçlarına göre; Türkiye'de bulunan 129 üniversitenin 67'inde SBEABD bulunmaktadır. Bu 67 üniversitenin 60'nda lisans programı, 50'sinde yüksek lisans programı ve 19'unda da doktora programı bulunmaktadır. SBEABD olan üniversitelerde 153 kadın, 370 erkek olmak üzere toplam 523 öğretim elemanı görev yapmaktadır. Öğretim elemanlarının kadro unvanları incelendiğinde; en fazla Doktor Öğretim Üyesi, sonrasında Doçent Doktor yer almaktadır. Öğretim elemanları daha çok Sosyal Bilgiler Ĕ̆̈itimi (SBE) ve Tarih alanlarında uzmanlaşmışlardır. SBEABD'nda kayıtlı en az öğrenci Kahramanmaraş Sütçü İmam Üniversitesinde (97) ve en fazla öğrenci de Pamukkale Üniversitesindedir (419). Öğretim elemanı başına düşen öğrenci sayısı en az Muş Alparslan Üniversitesi (15.1), en fazla ise Siirt Üniversitesidir (99.7). 2018 A ğustos ayı verilerine SBEABD'nda 17.076 kayıtlı öğrenci bulunmaktadır.

Anahtar Kelimeler: Türkiye, Sosyal bilgiler eğitimi, Yükseköğretim 


\title{
The Status of Higher Education in Social Studies Education in Turkey
}

\begin{abstract}
Education Faculties of the universities in Turkey, Department of Social Studies Education (DSSE) intended to examine the different variables of this research, the case study qualitative research methods was conducted as part of the method. The scope of the research is the state universities in Turkey. The criterion here is the state universities, which are DSSE within the Faculty of Education. Research; 2019 was made in January and February. The data were taken from the Higher Education Council (YÖK) Academic, YÖK Atlas, YÖK Thesis Screening and official web pages of universities. Descriptive analysis method and SPSS 25 package program were used for data analysis. According to the survey of 129 universities in Turkey the moment there are 67 DSSE. 60 of these 67 universities have undergraduate programs, 50 of them have master's degree programs, and 19 have doctoral programs. A total of 523 academic staff, 153 women and 370 men, work in universities with Social Studies Education (SSE). When the staff titles of the teaching staff are examined; most of them are Assistant Professor Doctor, then Associate Professor Doctor. The teaching staff is more specialized in Social Studies Education and History. The minimum number of students enrolled in the DSSE is in Kahramanmaraş Sütçü Imam University (97), and the highest number of students is at Pamukkale University (419). The minimum number of students per lecturer is Muş Alparslan University (15.1), and the highest is Siirt University (99.7). There are 17.076 registered students in DSSE in August 2018 data.
\end{abstract}

Keywords: Turkey, Social studies education, Higher education. 


\section{Giriş}

Türkiye'de öğretmen yetiştiren okulların tarihi, Darülmuallimin'in açıldığı 150 yıl öncesine kadar geri gider. Bugün Sosyal Bilgiler dersinin kapsamını oluşturan konuların anlatımı, Cumhuriyetin uzunca bir döneminde Vatandaşlık Bilgisi, Tarih ve Coğrafya derslerinde verilmişti. Örneğin, 1920'ler sonunda tarih öğretmeni olan Afet İnan akademiye geçmeden önce liselerde yurttaşlık eğitimi veriyordu (İnan, 2018. s.13). Ülkemizde Sosyal Bilgiler öğretmeni yetiştirmenin tarihçesi bu dersin Türk eğitim sisteminde yer almasıyla doğru orantılıdır. Başka bir ifadeyle 1968 öncesinde Sosyal Bilgiler öğretmen yetiştirme programlarından söz etmek mümkün değildir. Zira bu döneme egemen olan tek disiplinli yaklaşım anlayışı Sosyal Bilgiler konularını tarih ve coğrafya öğretmenlerinin okutmasını zorunlu kılmıştır. Bu bağlamda cumhuriyet döneminde Gazi Orta Muallim Mektebi ve Terbiye Enstitüsü bünyesinde tarih-coğrafya bölümünde öğretmen yetiştirilmesiyle başlayan süreç, 1967-1968 öğretim yılından itibaren üç yıllık eğitim enstitülerine bağlı edebiyat bölümünün Sosyal Bilgiler kısmında devam etmiştir (Altunya, 2006; Günay, 2017; Öztürk, 2005; Dursunoğlu, 2003; Güven, 2010). Eğitim enstitülerinin 19781979 eğitim-öğretim yılından itibaren dört yıllık yüksek öğretmen okullarına dönüştürülmesi esnasında Sosyal Bilgiler bölümü kaldırılarak yerine tarih-coğrafya ve coğrafya-tarih bölümleri kurulmuştur (Ercan, 2009). 1982 yılından itibaren yüksek öğretmen okullarının eğitim fakültelerine dönüştürülerek üniversitelere devredilmesi Sosyal Bilgiler öğretmeni yetiştirme usulünde başlangıçta bir değişikliğe neden olmamış ve Sosyal Bilgiler konu alanını öğretecek öğretmenler sosyal bilimler eğitimi bölümüne bağlı tarih ve coğrafya öğretmenliği anabilim dallarında yetiştirilmeye devam etmişlerdir (YÖK, 2007'den Akt. Kaymakc1, 2012. s.46; Güven, 2010 s.374).

Yükseköğretim Kurulu, 04.11.1997 tarih ve 97.39.2761 sayılı kararı ile eğitim fakültelerinde yeniden yapılanma sürecini başlatmış ve bu çerçevede 1998-1999 eğitim-öğretim yılından itibaren yeniden düzenlenen öğretmen yetiştirme programlarının uygulanmasına geçilmiştir (Çoban, 2010. s.30). Özellikle sekiz yıllık zorunlu-kesintisiz eğitime geçiş ve Sosyal Bilgilerin bütüncül bakış açısıyla ilköğretim 4. sınıftan 7. sınıfa 
kadar devam eden bir ders olarak yeniden ele alınması eğitim fakültelerinde ilköğretim bölümü bünyesinde Sosyal Bilgiler öğretmenliği programlarının açılmasını sağlamıştır (Kaymakçı, 2012. s.46; Erdoğan, 2014: s.336). 1997-1998 öğretim yılında sadece Celal Bayar, Selçuk ve Gazi Üniversitelerinin Eğitim Fakülteleri'nin Sosyal Bilgiler Öğretmenliği Programı'na öğrenci alınıyordu. Aynı yıl söz konusu programlara alınan toplam öğrenci sayısı ise, 190 kişi idi. 1998-1999 öğretim yılında ise, Sosyal Bilgiler Öğretmenliği Programına öğrenci alan eğitim fakültelerinin sayısı 28'e, toplam öğrenci kontenjanı ise, 2950 kişiye ulaşmıştır (Özav, 2001 s.166).

Sosyal Bilgiler öğretmenliği lisans programı açıldığı yıllarda SBE uzmanlık alanında yetişmiş öğretim elemanı bulunmadığından bölümün öğretim elemanı ihtiyacı fen ve edebiyat fakültelerinden sağlanmıştır. 2002 yılında Sosyal Bilgiler öğretmenliği programı ilk mezunlarını vermiş olup, ilk yüksek lisans öğrencilerini o yıl kabul etmiştir. Sosyal Bilgiler öğretmenliği lisans programından 2002 yılı ve sonraki yıllarda mezun olup lisansüstü eğitimlerine devam eden öğrenciler zamanla SBEABD'nda öğretim elemanı olarak görev almaya başlamışlardır. İlgili alan yazın incelendiğinde; gerektiği kadar araştırmanın yapılmadığı anlaşılmıştır. Konu ile ilgili (Abazoğlu, Yıldırım ve Yıldızhan, 2016; Baysan, Ercan ve Öztürk, 2011; Çoban, 2014; İnan, 2015; Kaymakçı ve Öztürk, 2011; Özer, 2011; Tokcan ve Tilki, 2017) benzer araştırmalarda bulunmuşlardır. Bu araştırmanın amacı da SBEABD'nın günümüzdeki durumunu; eğitimöğretim yapısı, öğretim elemanı yapısı vb. incelemek ve elde edilen verilerden bir sonuç ortaya çıkarmaktır. Bu amaçla araştırmada aşağıdaki sorulara cevap aranmıştır;

1) Türkiye' deki hangi üniversitelerde SBEABD bulunmaktadır?

2) Türkiye'deki hangi üniversitelerde SBEABD yüksek lisans programı bulunmaktadır?

3) Türkiye' deki hangi üniversitelerde SBEABD doktora programı bulunmaktadır?

4) Türkiye'de SBEABD olup da lisans öğrencisi olmayan üniversiteler hangileridir?

5) SBEABD'ndaki öğretim elemanı sayısı ne kadardır?

6) SBEABD'nda öğretim elemanı sayısının cinsiyet ve kadro unvanına göre dağılımı nasıldır? 
7) SBEABD'nda görev yapan öğretim elemanlarının uzmanlık alanları nedir?

8) SBEABD'nda görev yapan öğretim elemanlarının uzmanlık alanlarının cinsiyet ve kadro unvanına göre dağılımı nasıldır?

9) Türkiye'deki üniversitelerin SBEABD'nda görev yapan, uzmanlık alanı SBE olan öğretim elemanı sayısı ve üniversiteye göre oranı nedir?

10) Türkiye'deki üniversitelerin $S B E A B D$ 'na kayıtlı öğrenci sayısı ve öğretim elemanı başına düşen öğrenci oranı nedir?

\section{Yöntem}

$\mathrm{Bu}$ bölümde araştırmanın amacı doğrultusunda araştırmanın deseni, araştırma verileri, veri kaynakları ve verilerin çözümlenmesi açıklanmaya çalışılmıştır.

\section{Araştırmanın Deseni}

$\mathrm{Bu}$ araştırmada, nitel araştırma yöntemlerinden durum çalışması (case study) yöntemi kullanılmıştır. Durum çalışması, sınırlı bir sistemin derinlemesine betimlenmesi ve incelenmesidir (Merriam, 2013. s.40; Glesne, 2014. s.30). Durum çalışmasında durum; bir birey, grup, örgüt, durum veya ilgi duyulan herhangi bir şeydir (Rabson, 2017. s.159). Nitel durum çalışmasının en temel özelliği, bir ya da birkaç durumun derinliğine araştırılmasıdır. Yani bir duruma ilişkin etkenler (ortam, bireyler, olaylar, süreçler vb.) bütüncül bir yaklaşımla araştırılır ve ilgili durumu nasıl etkiledikleri ve ilgili durumdan nasıl etkilendikleri üzerine odaklanılır (Yıldırım ve Şimşek, 2018. s.83).

\section{Araştırma Verileri}

Araştırmada ölçüt örnekleme yöntemi tercih edilmiştir. Buradaki ölçüt, eğitim fakültelerinde SBEABD olan üniversitelerdir. Araştırma verileri Türkiye'de eğitim-öğretim faaliyetlerine devam eden YÖK'e bağlı 129 devlet üniversitesinin eğitim fakültelerinde SBEABD olan 67 devlet üniversitesine ait bilgiler oluşturmaktadır. 


\section{Veri Toplama Arac1}

Bu araştırmada; Türkiye'deki devlet üniversitelerinin eğitim fakülteleri bünyesinde bulunan SBEABD'nın çeşitli değişkenler açısından incelenmesi amaçlandığından doküman (belge) incelemesi yöntemi kullanılmıştır. Dokümanlar nitel olarak yürütülen araştırmalarda başvurulan önemli veri kaynaklarıdır. Doküman inceleme, araştırmanın konusu ile ilgili bilgi içeren materyallerin çözümlemesidir. Bu materyaller yazılı olabileceği gibi konuyla ilgili film, video veya fotoğraflar şeklinde de olabilir (Aktaş, 2014. s.363; Karasar, 2012. s.183; Yıldırım ve Şimşek, 2008 s.187; Merriam, 2013, s.132). Doküman çözümlemesi betimsel (tanımlayıcı) bir araştırma olarak kullanıldığında güncel belgeler ve olaylar odak noktalarıdır (Best ve Kahn, 2017, s.272). Araştırma için sağlanan dokümanların veri kaynakları Şekil 1'de verilmiştir.

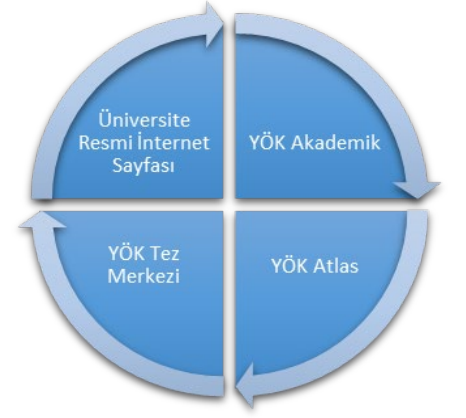

Şekil 1. Araştırmanın veri kaynakları

\section{Verilerin Çözümlenmesi}

Bu araştırmada veriler, YÖK Akademik, YÖK Atlas, YÖK Tez Merkezi ve SBEABD bulunan devlet üniversitelerinin resmi web sayfalarındaki öğretim elemanlarının kişisel web sayfalarından elde edilmiştir. Elde edilen veriler araştırmanın değişkenlerine göre kodlanarak, betimsel (tanımlayıcı) analiz yapılıp sonuca ulaşmaya çalışılmıştır. Belirlenen alt problemlere yönelik betimsel veriler için SPSS 25.0 paket programı kullanılmıştır. 


\section{Bulgular}

$\mathrm{Bu}$ bölümde araştırma soruları doğrultusunda betimsel verilerin sonuçlarına yer verilmiştir. Türkiye'deki devlet üniversitelerin SBEABD lisans ve lisansüstü programlarının sayısal verileri Grafik 1'de verilmiştir.

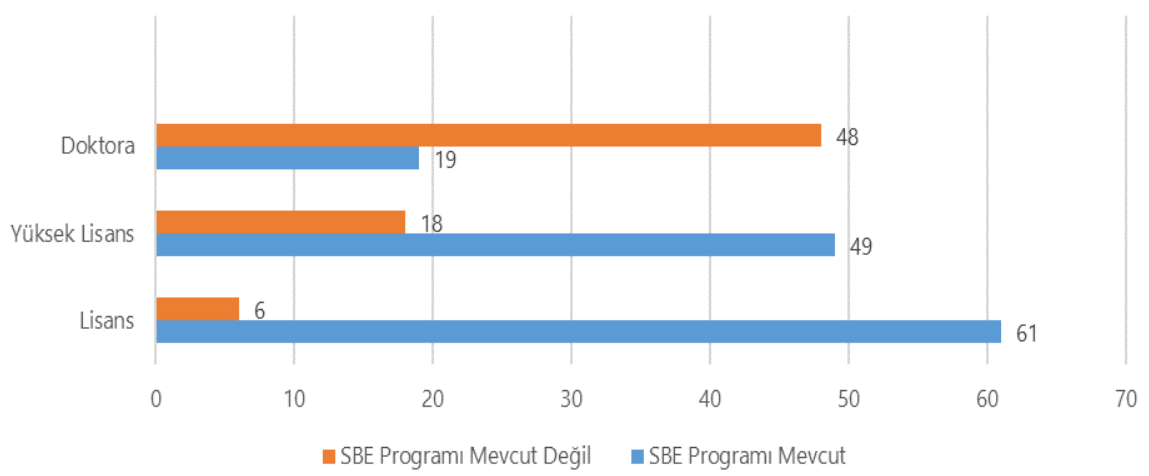

Grafik 1. Türkiye'deki Devlet Üniversitelerinin SBEABD Lisans ve Lisansüstü Programlarmin Durumu (2019)

Grafik 1 incelendiğinde; Türkiye'deki 129 devlet üniversitesinin eğitim fakültelerinin 67'sinde (\%51.93) SBEABD olduğu belirlenmiştir. Bu 67 devlet üniversitesinin 60'inda (\%89.55) lisans öğrencileri öğrenim görmektedir. Diğer 6 üniversitede ise ana bilim dalı olmakla birlikte lisans öğrencisi bulunmamaktadır. SBEABD olan 67 üniversitenin 50'sinde (\%74.62) yüksek lisans eğitimi, 19'unda da (\%28.35) doktora eğitimi programı bulunmaktadır. Her iki devlet üniversitesinin birinde SBEABD lisans programı bulunmaktadır. Mevcut lisans programlarının devamı niteliğinde her dört üniversitenin üçünde yüksek lisans eğitim programı, doktora eğitimi programı ise yaklaşık dört üniversitenin birinde bulunmaktadır. SBEABD doktora programının bu denli az olmasının nedeni olarak, YÖK'ün doktora eğitimi programı açma şartları olduğu ifade edilebilir. Öğretim elemanlarının uzmanlık alanı SBE olması bu şartlardan en önemlisidir. Türkiye'deki devlet üniversiteleri eğitim fakültelerinin SBEABD lisans programı olan üniversitelerin dağılımı Grafik 1'de verilmiştir. 


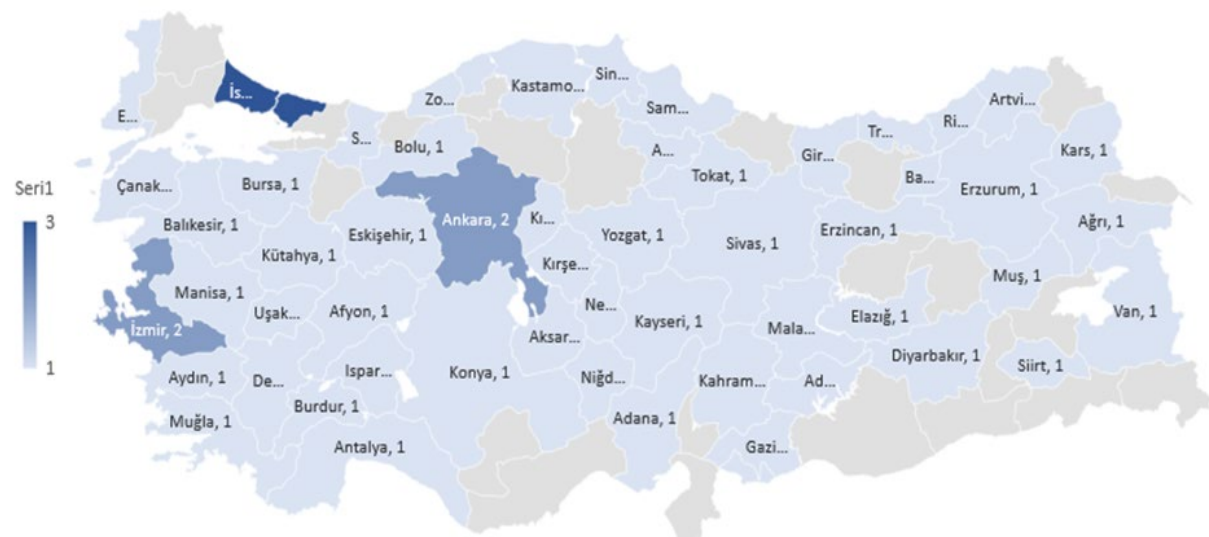

Grafik 1. SBEABD Lisans Programlarının Üniversite ve Şehre Göre Dă̆ılımı (2019).

Grafik 1 incelendiğinde; Türkiye'de devlet üniversiteleri eğitim fakültelerinde bulunan SBEABD lisans programlarının şehirlere göre dağılımı verilmiştir. Grafik 1'deki verilere göre; 60 devlet üniversitesinde bu program bulunmaktadır. SBEABD lisans programı diğer şehirlere oranla İstanbul, Ankara ve İzmir'de daha fazladır. İstanbul Üniversitesi-Cerrahpaşa, Marmara Üniversitesi ve Yıldız Teknik Üniversitesi İstanbul'da, Ankara ve Gazi Üniversitesi Ankara'da, Ege ve Dokuz Eylül Üniversitesi de İzmir'de yer almaktadır. Bu üç büyük şehrin haricinde birden fazla program olan şehir yoktur. Bölgelere göre incelendiğinde; en fazla olandan en az olana doğru sırasıyla Karadeniz Bölgesi'nde 13 (\%21.67), İç Anadolu Bölgesi'nde 12 (\%20.0), Ege Bölgesi'nde 9 (\%15.0), Marmara ve Doğu Anadolu Bölgelerinde 8'er (13.33), Akdeniz ve Güneydoğu Anadolu Bölgelerinde ise 5'er (\%8.33) SBEABDbulunmaktadır. Türkiye'deki devlet üniversiteleri eğitim fakültelerinin SBEABD yüksek lisans programı olan üniversitelerin dağılımı Grafik 2'de verilmiştir. 


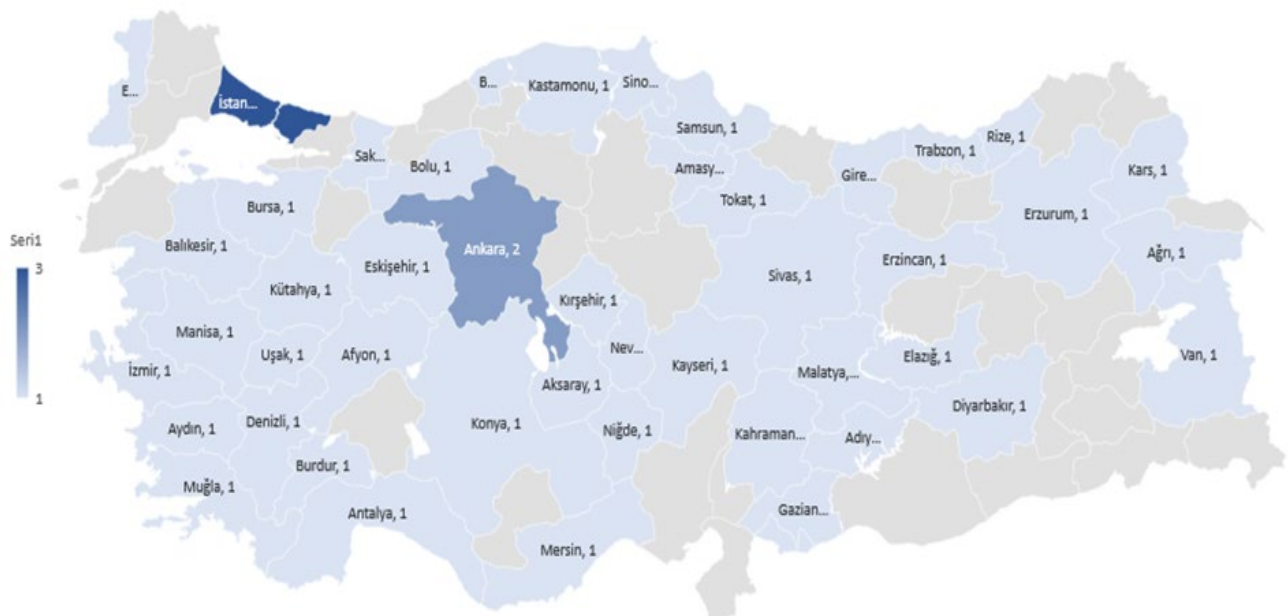

Grafik 2. SBEABD Yüksek Lisans Programlarının Üniversite ve Şehre Göre Dağılımı (2019)

Grafik 2'de Türkiye'deki devlet üniversitelerinde SBEABD yüksek lisans programı olan şehirler görülmektedir. Bu haritada, lisans programı olan şehirlerin dağılım haritasına göre daralma görülmektedir. En fazla yüksek lisans programının bulunduğu şehir İstanbul'dur. İstanbul'dan sonra iki yüksek lisans programı ile Ankara şehri gelmektedir. Bu iki şehrin haricinde mevcut üniversitelerde bir yüksek lisans programı bulunmaktadır. Ayrıca sayı olarak sırasıyla İç Anadolu Bölgesi'nde 10 (\%20.41), Karadeniz Bölgesi'nde 9 (\%18.37), Ege Bölgesi'nde 8 (\%16.33), Marmara ve Doğu Anadolu Bölgelerinde 7'şer (\%14.29), Akdeniz ve Güneydoğu Anadolu Bölgelerinde 4'er (\%8.16) tane SBEABD yüksek lisans programı bulunmaktadır. Bölgelere göre; Akdeniz ve Güneydoğu Anadolu Bölgelerinde, diğer bölgelere nazaran SBEABD yüksek lisans açısından daha zayıf kalmaktadır. Türkiye'deki devlet üniversiteleri eğitim fakültelerinin SBE$\mathrm{ABD}$ doktora programı olan üniversitelerin dağılımı Grafik 3'de verilmiştir. 


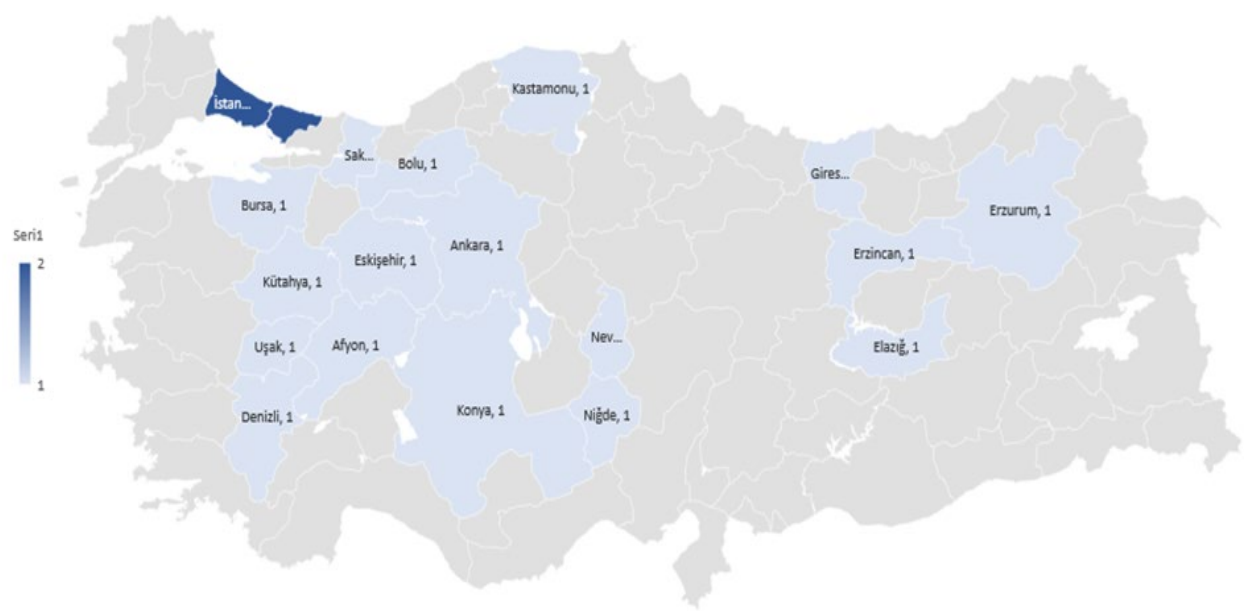

Grafik 3. SBEABD Doktora Programlarını Üniversite ve Şehre Göre Dağılımı (2019).

Grafik 3 incelendiğinde; Türkiye'deki SBEABD doktora programı olan şehirler bulunmaktadır. Ayrıca SBEABD doktora programı bulunan üniversiteler için Tablo 1'i inceleyiniz. Grafik 3'e göre, SBEABD doktora programı sadece İstanbul'da iki üniversitede, diğer mevcut şehirlerde ise bir üniversitede bulunmaktadır. Bunun yanında SBEABD doktora programı çoğunlukla Türkiye'nin batısındaki üniversitelerde olduğu görülmektedir. Bölgelere göre incelendiğinde; İç Anadolu Bölgesi'nde 5 (\%26.32), Ege ve Marmara Bölgelerinde 4'er (21.05) Karadeniz ve Doğu Anadolu Bölgelerinde ise 3'er (\%15.79) tane SBEABD doktora programı bulunmaktadır. Akdeniz ve Güneydoğu Anadolu Bölgelerinde SBEABD doktora programının bulunmadığı görülmektedir. Türkiye'deki üniversitelerin SBEABD lisans ve lisansüstü programlarının dağılımı Tablo 1'de verilmiştir. 
Tablo 1. Türkiye'deki Üniversitelerin SBEABD Lisans ve Lisansïstü Programlarının Dağıllımı (2019) 1

\begin{tabular}{|c|c|c|c|c|c|c|c|}
\hline Üniversite & L. & Y. L. & Dr. & Üniversite & L. & Y. L. & Dr. \\
\hline Ahi Evran & - & $\bullet$ & & Atatürk & - & - & - \\
\hline Üniversitesi & & & & Üniversitesi & & & \\
\hline Ordu Üniversitesi & & & & $\begin{array}{l}7 \text { Aralık } \\
\text { Üniversitesi }\end{array}$ & $\bullet$ & - & \\
\hline Ankara Üniversitesi & - & $\bullet$ & & $\begin{array}{l}\text { Uşak } \\
\text { Üniversitesi }\end{array}$ & $\bullet$ & - & - \\
\hline Gazi Üniversitesi & - & - & $\bullet$ & $\begin{array}{l}\text { Gaziantep } \\
\text { Ün. (Nizip) }\end{array}$ & - & - & \\
\hline $\begin{array}{l}\text { Necmettin } \\
\text { Erbakan Üni. }\end{array}$ & $\bullet$ & - & $\bullet$ & $\begin{array}{l}\text { Uludă̆ } \\
\text { Üniversitesi }\end{array}$ & $\bullet$ & - & $\bullet$ \\
\hline $\begin{array}{l}\text { Süleyman } \\
\text { Demirel Üni. }\end{array}$ & - & & & $\begin{array}{l}\text { Bayburt } \\
\text { Üniversitesi }\end{array}$ & $\bullet$ & & \\
\hline $\begin{array}{l}\text { Çukurova } \\
\text { Üniversitesi }\end{array}$ & $\bullet$ & & & $\begin{array}{l}\text { Erciyes } \\
\text { Üniversitesi }\end{array}$ & $\bullet$ & - & \\
\hline Dicle Üniversitesi & - & - & & $\begin{array}{l}\text { Yüzüncü } \\
\text { Yıl Üniversitesi }\end{array}$ & $\bullet$ & - & \\
\hline Bartın Üniversitesi & - & - & & $\begin{array}{l}\text { Mersin } \\
\text { Üniversitesi }\end{array}$ & & - & \\
\hline $\begin{array}{l}\text { Onsekiz Mart } \\
\text { Üniversitesi }\end{array}$ & - & & & $\begin{array}{l}\text { Mustafa } \\
\text { Kemal Üni. }\end{array}$ & & & \\
\hline $\begin{array}{l}\text { Anadolu } \\
\text { Üniversitesi }\end{array}$ & $\bullet$ & $\bullet$ & $\bullet$ & $\begin{array}{l}\text { Mehmet } \\
\text { Akif Ersoy Üni. }\end{array}$ & $\bullet$ & - & \\
\hline Recep Tayyip & - & - & & Kocaeli & & & \\
\hline Erdoğan Ün. & & & & Üniversitesi & & & \\
\hline $\begin{array}{l}\text { Balıkesir } \\
\text { Üniversitesi }\end{array}$ & - & - & & $\begin{array}{l}\text { Alaattin } \\
\text { Keykubat Üni. }\end{array}$ & & & \\
\hline $\begin{array}{l}\text { Sütçü İmam } \\
\text { Üniversitesi }\end{array}$ & $\bullet$ & - & & $\begin{array}{l}\text { Dumlupınar } \\
\text { Üniversitesi }\end{array}$ & $\bullet$ & - & $\bullet$ \\
\hline Gaziosmanpaşa Üni. & $\bullet$ & - & & $\begin{array}{l}\text { Pamukkale } \\
\text { Üniversitesi }\end{array}$ & $\bullet$ & - & $\bullet$ \\
\hline Amasya & - & - & & Ege & - & & \\
\hline Üniversitesi & & & & Üniversitesi & & & \\
\hline Osmangazi & & & & İbrahim & - & - & \\
\hline Üniversitesi & & & & Çeçen Üni. & & & \\
\hline $\begin{array}{l}\text { Giresun Üniversi- } \\
\text { tesi }\end{array}$ & - & - & - & $\begin{array}{l}\text { Kastamonu } \\
\text { Üniversitesi }\end{array}$ & - & - & - \\
\hline Akdeniz & - & - & & Ömer Halis & - & - & - \\
\hline Üniversitesi & & & & Üniversitesi & & & \\
\hline İnönü Üniversitesi & - & $\bullet$ & & $\begin{array}{l}\text { Adıyaman } \\
\text { Üniversitesi }\end{array}$ & $\bullet$ & - & \\
\hline $\begin{array}{l}\text { Kirıkkale } \\
\text { Üniversitesi }\end{array}$ & $\bullet$ & & & $\begin{array}{l}\text { Trakya } \\
\text { Üniversitesi }\end{array}$ & $\bullet$ & - & \\
\hline
\end{tabular}

${ }^{1}$ Tablo 1'deki sıralamada Karadağ ve Yücel'in (2018) Üniversite Araştırmaları Laboratuvarı (ÜniAr) kapsamında yapılan Devlet Üniversiteleri ve Fakülteleri Sıralaması esas alınmıştır. 


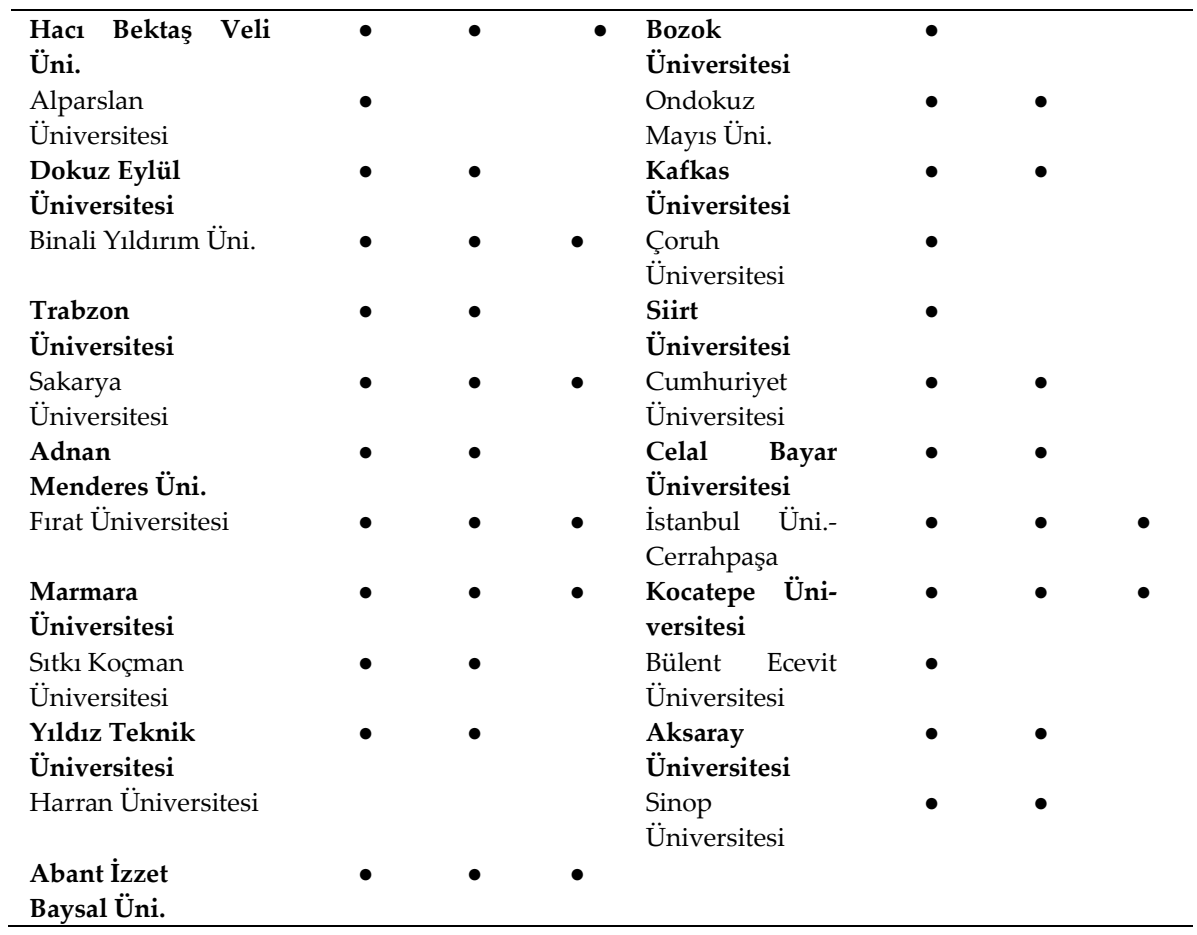

Tablo 1 incelendiğinde; 129 devlet üniversitesi içerisinde 60 devlet üniversitesinin SBEABD lisans programı olduğu görülmektedir. Ahi Evran Üniversitesi (Kırşehir), Ankara Üniversitesi, Gazi Üniversitesi (Ankara), Necmettin Erbakan Üniversitesi (Konya), Dicle Üniversitesi (Diyarbakır), Bartın üniversitesi, Anadolu Üniversitesi (Eskişehir), Recep Tayyip Erdoğan Üniversitesi (Rize), Balıkesir Üniversitesi, Sütçü İmam Üniversitesi (Kahramanmaraş), Gaziosmanpaşa Üniversitesi (Tokat), Amasya Üniversitesi, Giresun Üniversitesi, Akdeniz Üniversitesi (Antalya), İnönü Üniversitesi (Malatya), Hacı Bektaş Veli Üniversitesi (Nevşehir), Dokuz Eylül Üniversitesi (İzmir), Binali Yıldırım Üniversitesi (Erzincan), Trabzon Üniversitesi, Sakarya üniversitesi, Adnan Menderes Üniversitesi (Aydın), Fırat Üniversitesi (Elazığ), Marmara Üniversitesi (İstanbul), Sitkı Koçman Üniversitesi (Muğla), Yıldız Teknik Üniversitesi (İstanbul), Abant İzzet Baysal Üniversitesi (Bolu), Atatürk Üniversitesi (Erzurum), 7 Aralık Üniversitesi (Kilis), Uşak Üniversitesi, Gaziantep Üniversitesi (Nizip Eğitim Fakültesi), Uludağ Üniversitesi (Bursa), Erciyes Üniversitesi 
(Kayseri), Yüzüncü Yıl Üniversitesi (Van), Mehmet Akif Ersoy Üniversitesi (Burdur), Dumlupınar Üniversitesi (Kütahya), Pamukkale Üniversitesi (Denizli), İbrahim Çeçen Üniversitesi (Ağr1), Kastamonu Üniversitesi, Ömer Halisdemir Üniversitesi (Niğde), Adıyaman Üniversitesi, Trakya Üniversitesi (Edirne), Ondokuz Mayıs Üniversitesi (Samsun), Kafkas Üniversitesi (Kars), Cumhuriyet Üniversitesi (Sivas), Celal Bayar Üniversitesi (Manisa), İstanbul-Cerrahpaşa Üniversitesi, Kocatepe Üniversitesi (Afyon), Aksaray Üniversitesi, Mersin Üniversitesi ve Sinop Üniversitesi'nde toplam 50 SBEABD yüksek lisans programı olduğu görülmektedir.

Gazi Üniversitesi, Necmettin Erbakan Üniversitesi, Anadolu Üniversitesi, Giresun Üniversitesi, Hacı Bektaş Veli Üniversitesi, Binali Yıldırım Üniversitesi, Sakarya Üniversitesi, Frrat Üniversitesi, Marmara Üniversitesi, Abant İzzet Baysal Üniversitesi, Atatürk Üniversitesi, Uşak Üniversitesi, Uludağ Üniversitesi, Dumlupınar Üniversitesi, Pamukkale Üniversitesi, Kastamonu Üniversitesi, Ömer Halisdemir Üniversitesi, İstanbulCerrahpaşa Üniversitesi ve Kocatepe Üniversitelerinde SBEABD doktora programları olduğu görülmektedir. Ordu Üniversitesi, Eskişehir Osmangazi Üniversitesi, Şanlıurfa Harran Üniversitesi, Hatay Mustafa Kemal Üniversitesi, Mersin Üniversitesi ve Alanya Alaattin Keykubat üniversitesinin anabilim dalı olmasına rağmen lisans eğitimi programı olmadığ görülmektedir. SBEABD programlarında görev yapan öğretim elemanlarının üniversitelere göre dağılımı Tablo 2' de verilmiştir.

Tablo 2 incelendiğinde; SBEABD'nda görevli öğretim elemanı sayısı 10 ve üzeri olan; Amasya Üniversitesi (14), Muğla Sıtkı Koçman Üniversitesi (14), Gazi Üniversitesi (13), Anadolu Üniversitesi (13), Alparslan Üniversitesi (13), Erzincan Üniversitesi (13), Atatürk Üniversitesi (13), Pamukkale Üniversitesi (13), Giresun Üniversitesi (12), Trabzon Üniversitesi (12), İstanbul Üniversitesi (12), Necmettin Erbakan Üniversitesi (11), Uludağ Üniversitesi (11), Kastamonu Üniversitesi (11), Ömer Halisdemir Üniversitesi (11), Frrat Üniversitesi (10), Uşak Üniversitesi (10), Kocatepe Üniversitesi (10) ve Aksaray Üniversitesi'dir (10). Diğger yandan öğretim elemanı sayısı 5 ve altı olan; Çukurova Üniversitesi (5), İnönü Üniversitesi (5), Onsekiz Mart Üniversitesi (4), Sütçü İmam Üniversitesi (4), Kırıkkale Üniversitesi (4), Erciyes Üniversitesi (4), Mersin Üniversitesi (4), Mustafa Kemal Üniversitesi (4), Ordu Üniversitesi (3), Osmangazi Üniversitesi (3), Harran 
Üniversitesi (3), Gaziantep Üniversitesi (3), Kocaeli Üniversitesi (2), Alaattin Keykubat Üniversitesidir (2). SBEABD'nda görev yapan öğretim elemanlarının kadro unvanlarına göre dağılımı Grafik 2' de verilmiştir.

Tablo 2. SBEABD'nda Görev Yapan Öğretim Elemanlarının Üniversitelere Göre Dağılımı(2019)

\begin{tabular}{|c|c|c|c|c|c|}
\hline Üniversite & $\mathbf{N}$ & $\%$ & Üniversite & $\mathbf{N}$ & $\%$ \\
\hline Ahi Evran Üniversitesi & 8 & 1.5 & Atatürk Üniversitesi & 13 & 2.5 \\
\hline Ordu Üniversitesi & 3 & 0.6 & Kilis 7 Aralık Üniversitesi & 6 & 1.1 \\
\hline Ankara Üniversitesi & 8 & 1.5 & Uşak Üniversitesi & 10 & 1.9 \\
\hline Gazi Üniversitesi & 13 & 2.5 & Gaziantep Üniversitesi & 3 & 0.6 \\
\hline Necmettin Erbakan Üni. & 11 & 2.1 & Uludağ Üniversitesi & 11 & 2.1 \\
\hline Süleyman Demirel Üni. & 6 & 1.1 & Bayburt Üniversitesi & 6 & 1.1 \\
\hline Çukurova Üniversitesi & 5 & 1.0 & Erciyes Üniversitesi & 4 & 0.8 \\
\hline Dicle Üniversitesi & 8 & 1.5 & Yüzüncü Y1l Üniversitesi & 7 & 1.3 \\
\hline Bartın Üniversitesi & 7 & 1.3 & Mersin Üniversitesi & 4 & 0.8 \\
\hline Onsekiz Mart Üniversitesi & 4 & 0.8 & Mustafa Kemal Üni. & 4 & 0.8 \\
\hline Anadolu Üniversitesi & 13 & 2.5 & Mehmet Akif Ersoy Üni. & 6 & 1.1 \\
\hline Recep Tayyip Erdoğan Üni. & 8 & 1.5 & Kocaeli Üniversitesi & 2 & 0.4 \\
\hline Balıkesir Üniversitesi & 9 & 1.7 & Alaattin Keykubat Üni. & 2 & 0.4 \\
\hline Sütçü İmam Üniversitesi & 4 & 0.8 & Dumlupınar Üniversitesi & 9 & 1.7 \\
\hline Gaziosmanpaşa Üniversitesi & 7 & 1.3 & Pamukkale Üniversitesi & 13 & 2.5 \\
\hline Amasya Üniversitesi & 14 & 2.7 & Ege Üniversitesi & 6 & 1.1 \\
\hline Osmangazi Üniversitesi & 3 & 0.6 & Ağrr İbrahim Çeçen Üni. & 6 & 1.1 \\
\hline Giresun Üniversitesi & 12 & 2.3 & Kastamonu Üniversitesi & 11 & 2.1 \\
\hline Akdeniz Üniversitesi & 8 & 1.5 & Ömer Halisdemir Üni. & 11 & 2.1 \\
\hline İnönü Üniversitesi & 5 & 1.0 & Adıyaman Üniversitesi & 6 & 1.1 \\
\hline Kırıkkale Üniversitesi & 4 & 0.8 & Trakya Üniversitesi & 6 & 1.1 \\
\hline Hacı Bektaş Veli Üniversitesi & 6 & 1.1 & Bozok Üniversitesi & 6 & 1.1 \\
\hline Alparslan Üniversitesi & 13 & 2.5 & Ondokuz Mayıs Üni. & 7 & 1.3 \\
\hline Dokuz Eylül Üniversitesi & 9 & 1.7 & Kafkas Üniversitesi & 7 & 1.3 \\
\hline Erzincan Üniversitesi & 13 & 2.5 & Çoruh Üniversitesi & 6 & 1.1 \\
\hline Trabzon Üniversitesi & 12 & 2.3 & Siirt Üniversitesi & 5 & 1.0 \\
\hline Sakarya Üniversitesi & 7 & 1.3 & Cumhuriyet Üniversitesi & 9 & 1.7 \\
\hline Adnan Menderes Üniversitesi & 8 & 1.5 & Manisa Celal Bayar Üni. & 9 & 1.7 \\
\hline Firat Üniversitesi & 10 & 1.9 & İstanbul Üniversitesi & 12 & 2.3 \\
\hline Marmara Üniversitesi & 8 & 1.5 & Afyon Kocatepe Üni. & 10 & 1.9 \\
\hline S1tkı Koçman Üniversitesi & 14 & 2.7 & Bülent Ecevit Üniversitesi & 9 & 1.7 \\
\hline Yıldız Teknik Üniversitesi & 9 & 1.7 & Aksaray Üniversitesi & 10 & 1.9 \\
\hline Harran Üniversitesi & 3 & 0.6 & Sinop Üniversitesi & 7 & 1.3 \\
\hline Abant İzzet Baysal Üni. & 8 & 1.5 & & & \\
\hline Toplam & & & & 523 & 100.0 \\
\hline
\end{tabular}




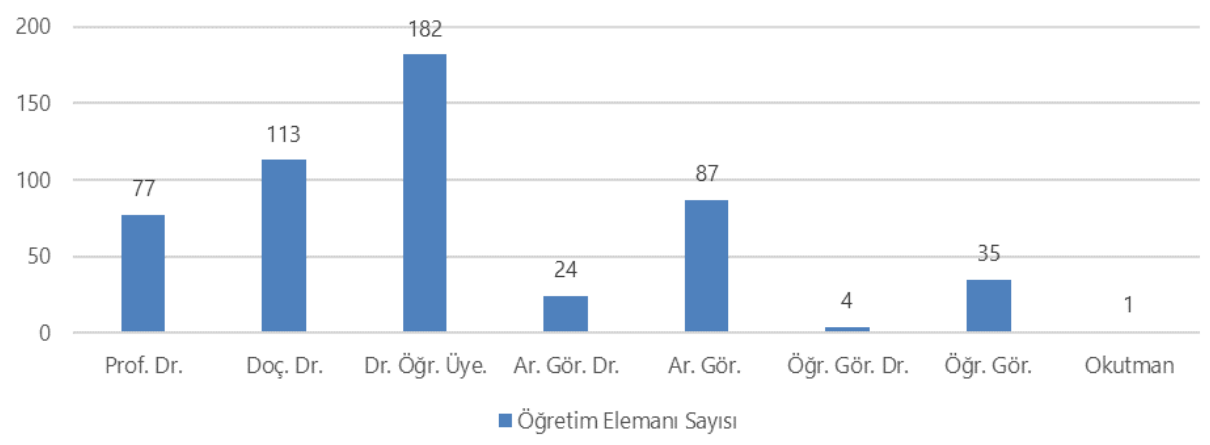

Grafik 2. SBEABD'nda Görev Yapan Öğretim Elemanlarmın Kadro Unvanlarına Göre Dağılımı (2019)

Grafik 2 incelendiğinde; Türkiye'deki devlet üniversiteleri Eğitim Fakültesi SBEABD'nda görev yapan öğretim elemanlarının kadro unvan ve sayıları verilmektedir. Bu verilere göre; SBEABD'nda 77 Prof. Dr. (\%14.7), 113 Doç. Dr. (\%21.6), 182 Dr. Öğr. Üyesi (\%34.7), 24 Ar. Gör. Dr. (\%4.5), 87 Ar. Gör. (\%16.6), 4 Öğr. Gör. Dr. (\%0.7), 35 Öğr. Gör. (\%6.6) ve 1 Okutman (\%0.1) görev yapmaktadır. Bu durumda Dr. Öğr. Üyesi kadro unvanına sahip öğretim eleman sayısının diğerlerinden sayı olarak daha fazla olduğu görülmektedir. Diğer yandan Ar. Gör. Dr., Öğr. Gör. Dr., Öğrr. Gör. ve Okutman kadro unvanındaki öğretim elemanı sayısı diğerlerine nazaran daha az sayıda olduğu görülmektedir. SBEABD'nda görev yapan öğretim elemanlarının kadro unvanlarına ve cinsiyete göre dağılımı Grafik 3'te verilmiştir.

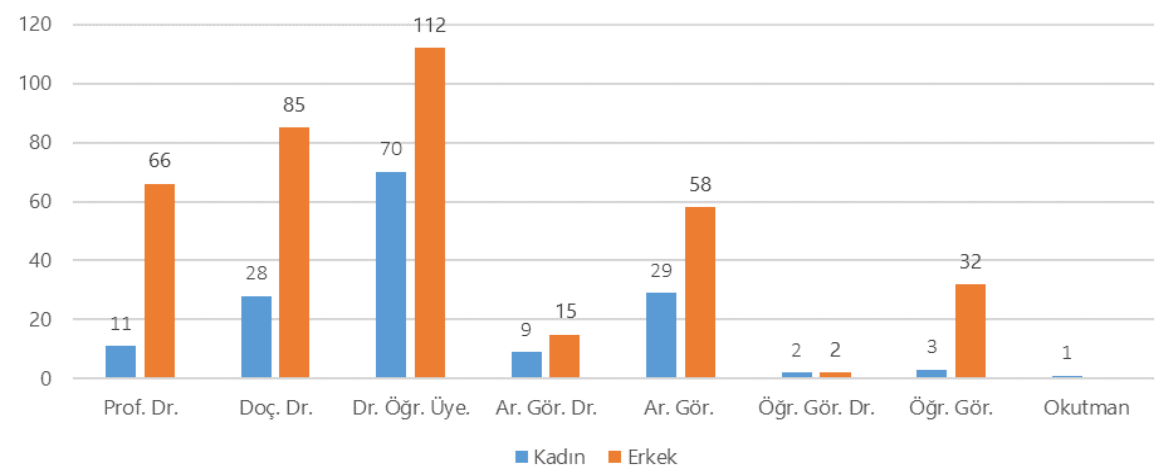

Grafik 3. SBEABD'nda Görev Yapan Öğretim Elemanlarının Kadro Unvanlarına ve Cinsiyete Göre Dă̆ılımı (2019) 
Grafik 3 incelendiğinde; Türkiye'deki devlet üniversitelerinin Eğitim Fakültesi SBEABD'nda görev yapan Prof. Dr. kadro unvanına sahip öğretim elemanlarının 11'i (14.2) kadın, 66'sı (85.7) erkektir. Doç. Dr. kadro unvanına sahip 28 (\%24.7) kadın, 85 (\%75.2) erkek öğretim elemanı bulunmaktadır. Dr. Öğr. Üyesi kadro unvanında 70 (\%38.4) kadın, 112 (\%61.5) erkek öğretim elemanı görev yapmaktadır. Ar. Gör. Dr. kadro unvanında 9 (\%37.5) kadın, 15 (\%62.5) erkek öğretim elemanı bulunmaktadır. Ar. Gör. kadrosunda 29 (\%33.3) kadın, 58 (\%66.6) erkek öğretim elemanı görev yapmaktadır. Öğr. Gör. Dr. kadro unvanında 2 (\%50) kadın ve 2 (\%50) erkek öğretim elemanı yer almaktadır. Öğr. Gör. kadro unvanına sahip 3 (\%8.5) kadın, 32 (\%91.5) erkek öğretim elemanı bulunmaktadır. Son olarak 1 (\%100) kadın öğretim elemanı Okutman olarak görev yapmaktadır. SBEABD'nda görev yapan öğretim elemanları cinsiyet açısından incelendiğinde hemen hemen her kadro unvanlarında erkek öğretim elemanı oranı daha fazla olmakla birlikte kadın ve erkek öğretim elemanı sayısının birbirine en çok yaklaştığ $\mathrm{Dr}$. Öğr. Üyesi kadro unvanıdır. SBEABD'nda görev yapan öğretim elemanlarının uzmanlık alanlarına göre dağılımı Grafik 4'te verilmiştir.

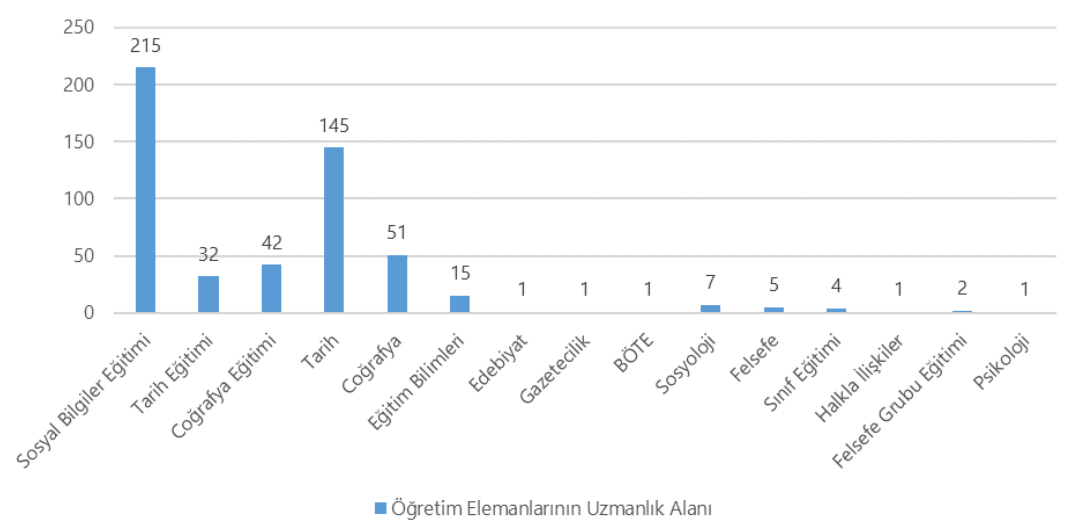

Grafik 4. SBEABD'nda Görev Yapan Öğretim Elemanlarının Uzmanlık Alanlarına Göre Dă̆̊lımı (2019)

Grafik 4 incelendiğinde; Türkiye'de SBEABD'nda görev yapan öğretim elemanlarının uzmanlık alanlarına göre dağılımı verilmiştir. Buna göre öğretim elemanlarının 215'i (41.1) SBE, 32'si (6.1) Tarih Eğitimi, 42'si (\%8.0) 
Coğrafya Eğitimi, 145'i (\%27.7) Tarih, 51'i (\%9.7) Coğrafya, 15'i (\%2.8) Eğitim Bilimleri, 7'si (\%1.3) Sosyoloji, 5'i (\%0.9) Sınıf Eğitimi, 2'si (0.3) Felsefe Grubu Eğitimi alanında uzmanlığı bulunmaktadır. Edebiyat, Gazetecilik, Bilgisayar ve Öğretim Teknolojileri (BÖTE), Halkla İlişkiler ve Psikoloji alanında 1 (\%0.1) öğretim elemanı uzman olarak görülmektedir. Bu verilerden Türkiye'deki SBEABD'nda görev yapan öğretim elemanlarının öncelikle $S B E$ ve daha sonra da Tarih, Coğrafya, Coğrafya Eğitimi, Tarih Eğitimi ve Eğitim Bilimleri alanlarında uzmanlaştıkları görülmektedir. Sosyal bilimlerin diğer alanlarında uzman sayısı ise oldukça az olduğu görülmektedir. SBEABD'nda görev yapan öğretim elemanlarının uzmanlık alanlarına ve cinsiyete göre dağglımı Grafik 5'te verilmiştir.

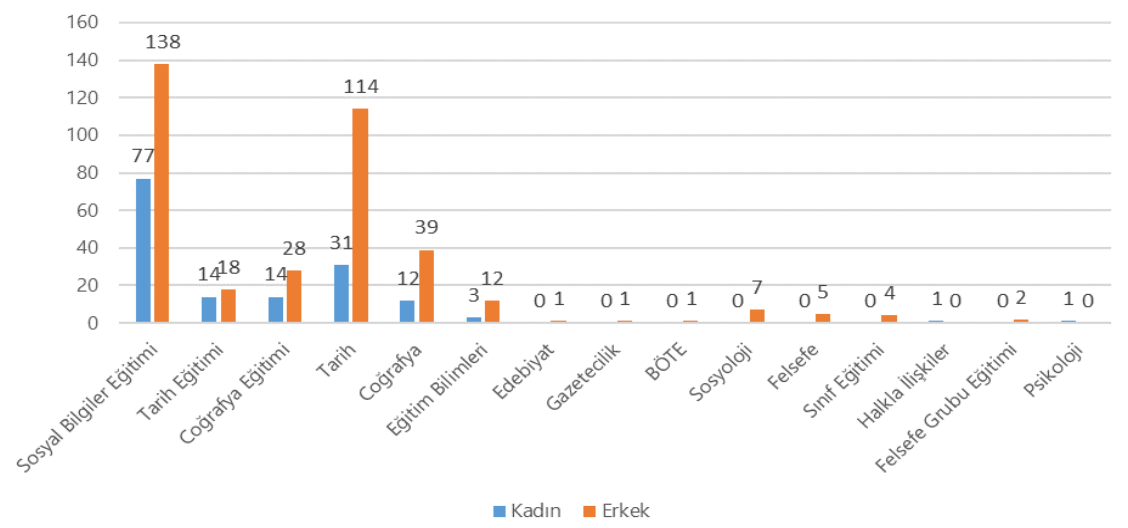

Grafik 5. SBEABD'nda Görev Yapan Öğretim Elemanlarının Uzmanlık Alanları ve Cinsiyete Göre Dă̆ılımı (2019)

Grafik 5 incelendiğinde; SBEABD'nda görev yapan ve uzmanlık alanı $S B E$ olan 77 (\%35.8) kadın, 138 (\%64.1) erkek; Tarih Eğitimi'nde uzman 14 (\%43.7) kadın, 18 (\%56.3) erkek; Coğrafya Eğitimi alanında uzman 14 (\%33.3), 28 (\%66.6) erkek; Tarih alanında uzman 31 (\%21.3) kadın, 114 (\%78.6) erkek; Coğrafya alanında 12 (\%23.5) kadın, 39 (\%76.4) erkek öğretim elemanı bulunmaktadır. Sosyoloji alanında 7 (\%100) erkek, Felsefe alanında 5 (\%100) erkek, Sinıf Ĕ̆itimi alanında 4 (\%100) erkek, Felsefe Grubu Eğitimi alanında 2 (\%100) erkek, Edebiyat alanında 1 (\%100) erkek, Gazetecilik alanında 1 (\%100) erkek, BÖTE alanında uzman 1 (\%100) erkek öğretim elemanı bulunmaktadır. Diğer yandan Halkla İlişkiler ve Psikoloji alanlarında uzman 1'er (\%100) kadın öğretim elemanı bulunmaktadır. 
SBEABD'nda görev yapan öğretim elemanları cinsiyet değişkenine göre incelendiğinde; 1'er öğretim elemanının uzman olduğu Halkla İlişkiler ve Psikoloji alanları hariç tüm sosyal bilim alanlarında erkek öğretim elemanlarının çoğunlukta olduğu görülmektedir. Kadın ve erkek öğretim eleman sayılarının birbirine en yakın olduğu alanlar ise Tarih Eğitimi ve Coğrafya Eğitimi alanları olduğu görülmektedir. SBEABD'nda görev yapan öğretim elemanlarının (Prof. Dr.) üniversite ve şehre göre dağılımı Grafik 4'te verilmiştir.

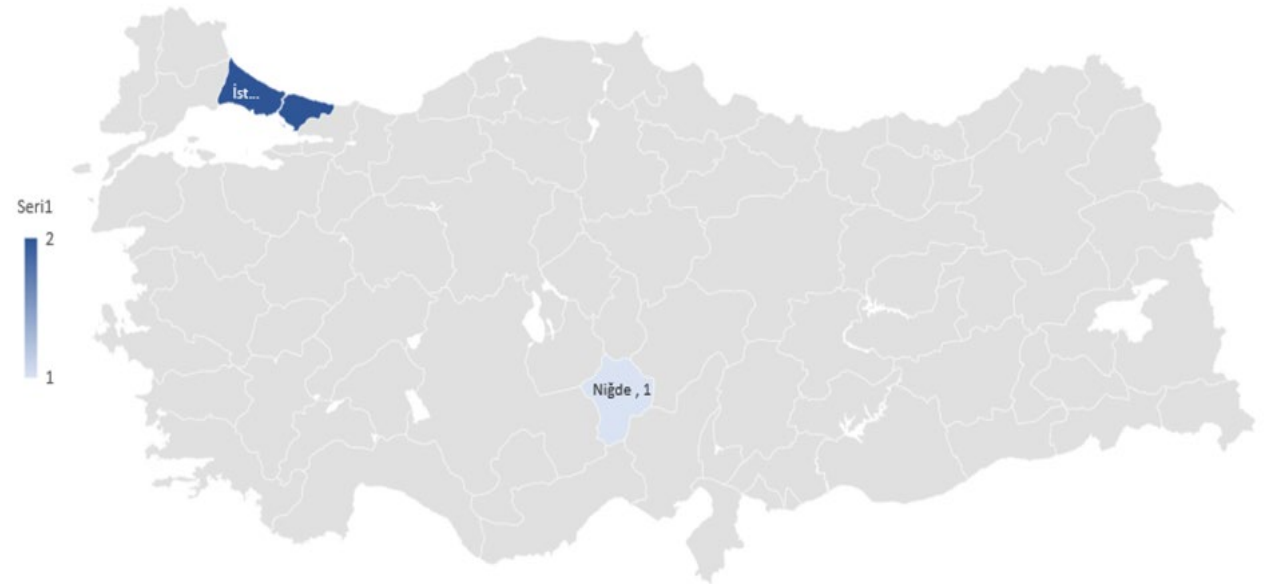

Grafik 4. SBEABD'nda Görev Yapan Öğretim Elemanlarının (Prof. Dr.) Üniversite ve Şehre Göre Dă̆̊lımı (2019)

SBEABD'nda Grafik 3'te görüldügü üzere toplam 77 Prof. Dr. kadro unvanına sahip öğretim elemanı görev yapmakta olup, bunlardan yalnızca üç (3) Prof. Dr.'un uzmanlık alanı SBE olduğu sonucuna ulaşılmıştır. Grafik 4'e göre bu Prof. Dr.'dan ikisi İstanbul'da Marmara Üniversitesi ve İstanbul Üniversitesi-Cerrahpaşada diğeri de Niğde Üniversitesinde görev yapmaktadır. SBEABD'nda görev yapan öğretim elemanlarının (Doç. Dr.) üniversite ve şehre göre dağılımı Grafik 5'te verilmiştir. 


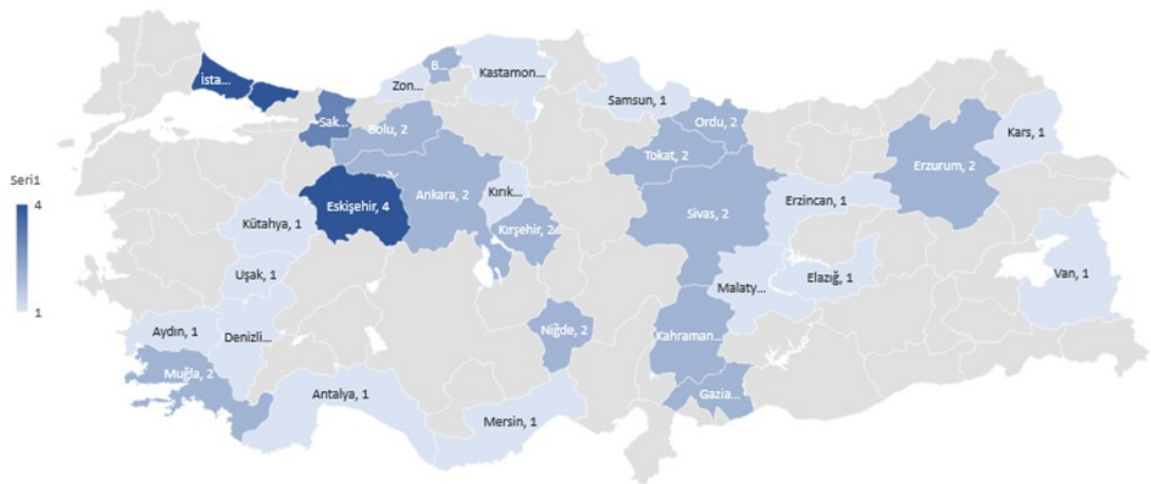

Grafik 5. SBEABD'nda Görev Yapan Öğretim Elemanlarının (Doç. Dr.) Üniversite ve Şehre Göre Dağılımı (2019)

Türkiye'de devlet üniversitelerinde SBEABD'nda Doç. Dr. kadro unvanına sahip 113 öğretim elemanı görev yapmaktadır. Ancak bu 113 Doç. $D r$.'un 50'sinin uzmanlık alanının $S B E$ olduğu sonucuna ulaşılmıştır. Uzmanlık alanı $S B E$ olan Doç. Dr.'ların şehirlere göre dağılımı Grafik 5'te verilmiştir. Buna göre uzmanlık alanı SBE olan en fazla Doç. Dr.'un İstanbul, Eskişehir ve Sakarya şehirlerinde görev yaptığı görülmektedir. Diğer yandan bazı üniversitelerde 2, bazı üniversitelerde 1 Doç. Dr. olmasına rağmen bazı üniversitelerde uzmanlık alanı $S B E$ olan Doç. Dr. kadro unvanına sahip öğretim elemanı bulunmamaktadır. (Bkz. Tablo 3.) SBEABD’nda görev yapan öğretim elemanlarının (Dr. Öğr. Üyesi) üniversite ve şehre göre dağılımı Grafik 6'da verilmiştir.

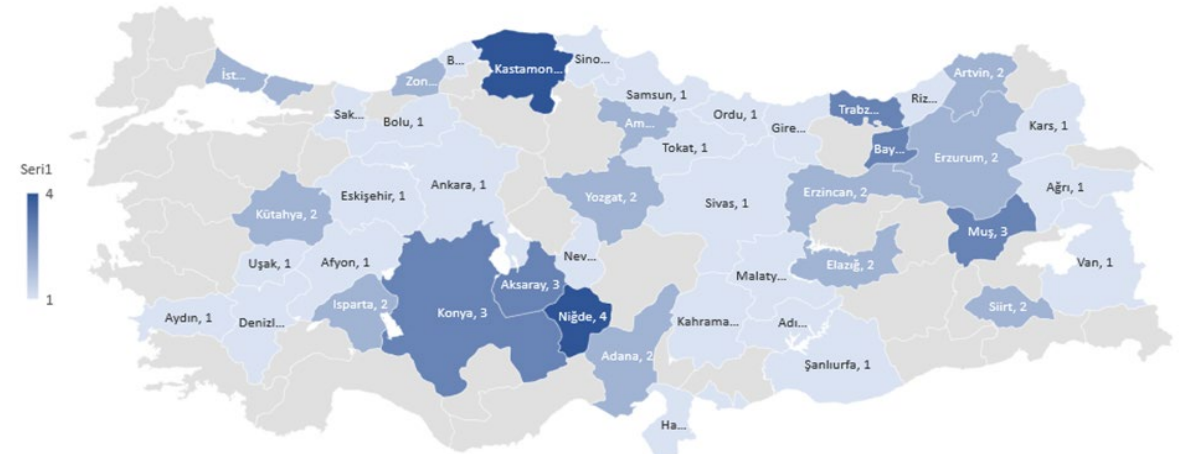

Grafik 6. SBEABD'nda Görev Yapan Öğretim Elemanlarının (Dr. Öğr. Üyesi) Üniversite ve Şehre Göre Dă̆ılımı (2019) 
SBEABD'nda en fazla Dr. Öğr. Üyesi kadro unvanına sahip öğretim elemanı görev yapmaktadır. Grafik 2'ye göre 182 Dr. Öğr. Üyesi bulunmaktadır. Bu öğretim elemanlarından 73'ünün uzmanlık alanı $S B E$ olduğu görülmektedir (Bkz. Tablo 3). Hem genel anlamda hem de $S B E$ uzmanlık alanı bağlamında Dr. Öğr. Üyesi kadro unvanına sahip öğretim elemanları, SBE açısından önemli bir konumda olduğu verilerden anlaşılmaktadır. SBEABD'nda görev yapan öğretim elemanlarının üniversite ve şehre göre dağılımı Grafik 7'de verilmiştir.

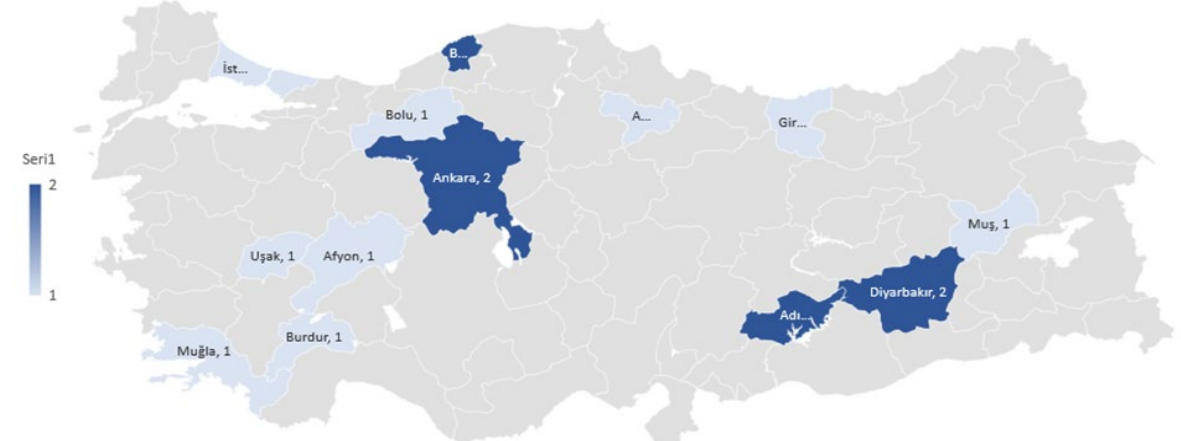

Grafik 7. SBEABD'nda Görev Yapan Öğretim Elemanlarının (Ar. Gör. Dr.) Üniversite ve Şehre Göre Dă̆ılımı (2019)

SBEABD’nda Ar. Gör. Dr. kadrosunda görev yapan öğretim elemanlarının şehirlere göre dağılımı Grafik 7'de görülmektedir. Buna göre; Ankara, Bartın, Adıyaman ve Diyarbakır'da 2'şer adet Ar. Gör. Dr. bulunmaktadır. Diğer şehirlerde birer adet Araştırma Görevlisi Doktor bulunmaktadır (Bkz. Tablo 3). Ar. Gör. Dr.'lar; doktorasını bitirmiş ve Dr. Öğr. Üyesi kadro unvanını bekleyen öğretim elemanlarıdır. Grafik 3 incelendiğinde; SBEABD'nda görevli olan Ar. Gör. Dr.'ların büyük çoğunluğunun uzmanlık alanı $S B E$ olduğu görülmektedir. SBEABD'nda görev yapan öğretim elemanlarının (Ar. Gör.) üniversite ve şehre göre dağılımı Grafik 8'de verilmiştir. 


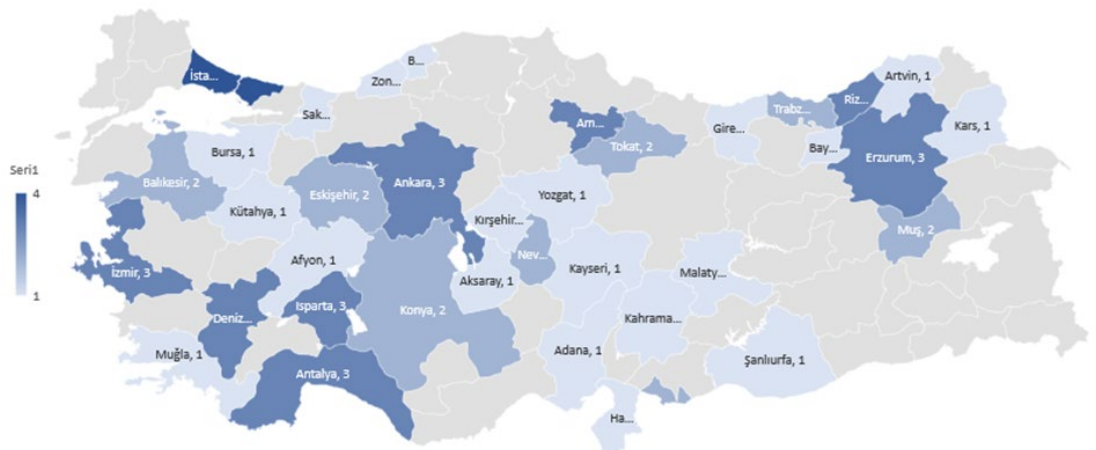

Grafik 8. SBEABD'nda Görev Yapan Öğretim Elemanlarını (Ar. Gör.) Üniversite ve Şehre Göre Dağılımı (2019)

SBEABD'nda görev yapan Araştırma Görevlilerinin dağılımı Grafik 8'de görülmektedir. Ar. Gör. olan ve olmayan üniversiteler için Tablo 3'ü inceleyiniz. Ar. Gör. olan şehirlerde en az bir (1) adet, en fazla (4) adet olduğu görülmektedir. SBEABD'nda Ar. Gör. en fazla olan; İstanbul, Ankara, Denizli, Isparta, Antalya, Amasya, Trabzon ve Erzurum şehirleridir. SBEABD'nda görev yapan öğretim elemanlarının (Öğr. Gör. Dr. ve Öğr. Gör.) üniversite ve şehre göre dağılımı Grafik 9'da verilmiştir.

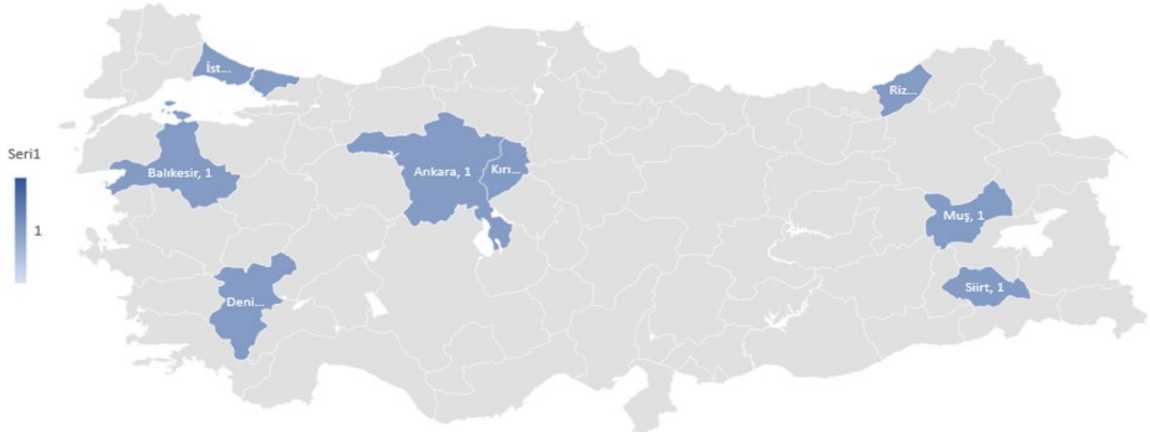

Grafik 9. SBEABD'nda Görev Yapan Öğretim Elemanlarının (Öğr. Gör. Dr. ve Öğr. Gör.) Üniversite ve Şehre Göre Dağılımı (2019)

Grafik 9 incelendiğinde; Türkiye'de üniversitelerde SBEABD'nda görev yapan Öğrr. Gör. dağılımı görülmektedir. Öğr. Gör.'in görev yaptığ 1 üniversiteler için Tablo 3'ü inceleyiniz. Grafik 9'dan anlaşıldığı üzere SBEABD'nda görev yapan öğretim elemanlarının sayısı kadro unvanına göredüşünüldügüünde; Öğr. Gör. oranının az olduğu görülmektedir. Tablo 
3'de uzmanlık alanı SBE olan öğretim elemanlarının üniversitelere göre dağılımı verilmiştir.

Tablo 3. Uzmanlık Alanı Sosyal Bilgiler Eğitimi Olan Öğretim Elemanlarının Üniversitelere Göre

\begin{tabular}{|c|c|c|c|c|c|c|c|c|c|c|}
\hline \multicolumn{11}{|c|}{ Sosyal Bilgiler Eğitimi Uzmanlık Alanı } \\
\hline & $1^{2}$ & 2 & 3 & 4 & 5 & 6 & 7 & Top. & Gen. & $\%$ \\
\hline Ahi Evran Ün. & & 2 & & & 1 & & & 3 & 8 & 37.5 \\
\hline Ordu Üniversitesi & & 2 & 1 & & & & & 3 & 3 & 100 \\
\hline Ankara Üni. & & & & & 2 & & & 2 & 8 & 25 \\
\hline Gazi Üniversitesi & & 2 & 1 & 2 & 1 & 1 & & 7 & 14 & 50 \\
\hline N. Erbakan Ün. & & & 3 & & 2 & & & 5 & 10 & 50 \\
\hline S. Demirel Üni. & & & 2 & & 3 & & & 5 & 6 & 83.3 \\
\hline Çukurova Üni. & & & 2 & & 1 & & & 3 & 5 & 60 \\
\hline Dicle Üniversitesi & & & & 2 & & & & 2 & 8 & 25 \\
\hline Bartın Üniversitesi & & 2 & 1 & 2 & 1 & & & 6 & 7 & 85.7 \\
\hline Onsekiz Mart Üni. & & & & & & & & 0 & 4 & 0 \\
\hline Anadolu Üni. & & 3 & 1 & & 2 & & & 6 & 13 & 46.1 \\
\hline R. T. Erdoğan Üni. & & & 1 & & 3 & & 1 & 5 & 8 & 62.5 \\
\hline Balıkesir Üni. & & & & & 2 & & 1 & 3 & 9 & 33.3 \\
\hline Sütçü İmam Üni. & & 2 & 1 & & 1 & & & 4 & 4 & 100 \\
\hline G.Osmanpaşa Üni. & & 2 & 1 & & 2 & & & 5 & 7 & 71.4 \\
\hline Amasya Üni. & & & 2 & 1 & 3 & & & 6 & 14 & 42.8 \\
\hline Osmangazi Üni. & & 1 & & & & & & 1 & 3 & 33.3 \\
\hline Giresun Üni. & & & 1 & 1 & 1 & & & 3 & 12 & 25 \\
\hline Akdeniz Üni. & & 1 & & & 2 & & & 3 & 8 & 37.5 \\
\hline İnönü Üniversitesi & & 1 & 1 & & 1 & & & 3 & 5 & 60 \\
\hline Kırıkkale Üni. & & 1 & & & & 1 & & 2 & 4 & 50 \\
\hline H. Bektaş Veli Ün. & & & 1 & & 2 & & & 3 & 6 & 50 \\
\hline Muş Alparslan Ün. & & & 3 & 1 & 2 & & 1 & 7 & 13 & 53.8 \\
\hline Dokuz Eylül Üni. & & & & & 2 & & & 2 & 9 & 22.2 \\
\hline Binali Yıldırım Ün. & & 1 & 2 & & & & & 3 & 13 & 23 \\
\hline Trabzon Üni. & & & 3 & & 2 & & & 5 & 12 & 41.6 \\
\hline Sakarya Üni. & & 3 & 1 & & 1 & & & 5 & 7 & 71.4 \\
\hline A. Menderes Üni. & & 1 & 1 & & & & & 2 & 8 & 25 \\
\hline Fırat Üniversitesi & & 1 & 2 & & & & & 3 & 10 & 30 \\
\hline Marmara Üni. & 1 & 2 & & & & 1 & & 4 & 8 & 50 \\
\hline
\end{tabular}

2 1-Prof. Dr., 2-Doç. Dr., 3-Dr. Öğr. Üye., 4-Ar. Gör. Dr., 5-Ar. Gör., 6-Öğr. Gör. Dr., 7-Öğr. Gör. 


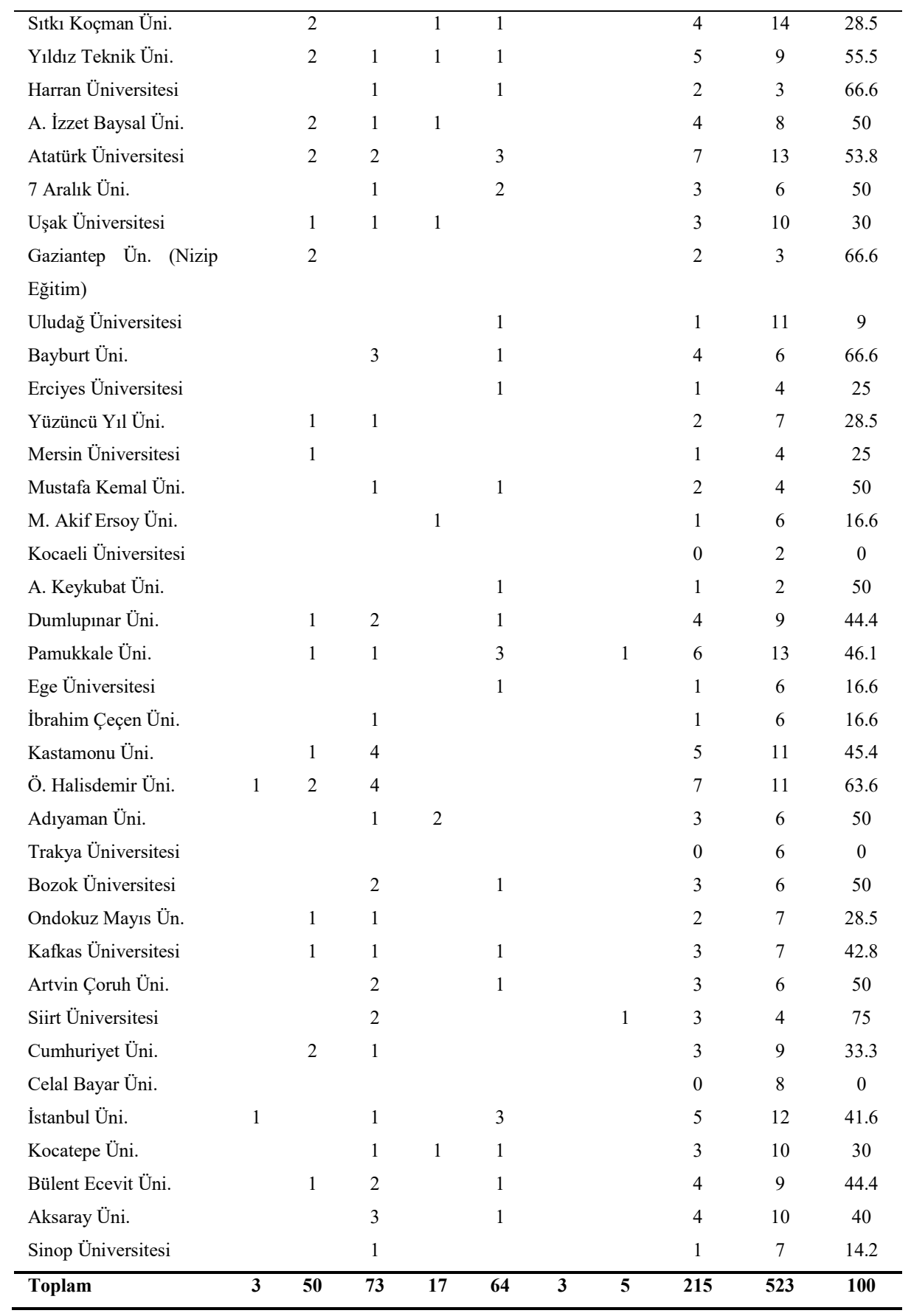


Tablo 3 incelendiğinde; Türkiye'deki üniversitelerde SBEABD'nda görev yapan ve uzmanlık alanı $S B E$ olan öğretim elemanlarının kadro unvanına göre dağılımı verilmektedir. Buna göre; uzmanlık alanı SBE olan 73 (\%33.95) Dr. Öğr. Üyesi, 64 (\%29.77) Ar. Gör., 50 (\%23.26) Doç. Dr., 17 (\%7.91) Ar. Gör. Dr., 5 (\%2.33) Öğr. Gör., 3'er (\%1.40) Prof. Dr. ve Öğr. Gör. bulunmaktadır. Üniversitelerin SBEABD'nda görev yapan uzmanlık alanı SBE olan öğretim elemanlarının, aynı programdaki bütün öğretim elemanlarına oranı dört aşamada incelenebilir. Bu gruplar A, B, C ve D grupları olarak isimlendirilmiştir.

A gurubunda olan üniversitelerde SBEABD'nda uzmanlık alanı SBE olan öğretim elemanlarının sayısı programdaki bütün öğretim elemanlarının sayısının yarısından fazla olan gruptur. Bunlar; Ordu Üniversitesi (\%100), Sütçü İmam Üniversitesi (\%100), Bartın Üniversitesi (\%85.7), Süleyman Demirel Üniversitesi (\%83.3), Siirt üniversitesi (\%75), Gaziosmanpaşa Üniversitesi (\%71.4), Sakarya Üniversitesi (\%71.4), Harran Üniversitesi (\%66.6), Gaziantep Üniversitesi Nizip Eğitim Fakültesi (\%66.6), Bayburt Üniversitesi (\%66.6), Ömer Halisdemir Üniversitesi (\%63.6), Recep Tayyip Erdoğan Üniversitesi (\%62.5), Çukurova Üniversitesi (\%60), İnönü Üniversitesi (\%60), Yıldız Teknik Üniversitesi (\%55.5), Alparslan Üniversitesi (\%53.8) ve Atatürk Üniversitesidir (\%53.8).

B grubu; uzmanlık alanı SBE olan öğretim elemanı sayısı ve programdaki diğer uzmanlık alanlarına sahip öğretim elemanı sayısının eşit olduğu üniversitelerdir. B grubunda; Gazi Üniversitesi (\%50), Necmettin Erbakan Üniversitesi (\%50), Kırıkkale Üniversitesi (\%50), Hacı Bektaş Veli Üniversitesi (\%50), Marmara Üniversitesi (\%50), Abant İzzet Baysal Üniversitesi (\%50), 7 Aralık Üniversitesi (\%50), Mustafa Kemal üniversitesi (\%50), Alaattin Keykubat Üniversitesi (\%50), Adıyaman Üniversitesi (\%50), Bozok Üniversitesi (\%50) ve Çoruh Üniversitesidir (\%50).

Uzmanlık alanı SBE olan öğretim eleman sayısının daha az olduğu C grubudur. Pamukkale Üniversitesi (\%46.1), Anadolu Üniversitesi (\%46.1), Kastamonu Üniversitesi (\%45.4), Dumlupınar Üniversitesi (\%44.4), Bülent Ecevit Üniversitesi (\%44.4), Kafkas Üniversitesi (\%42.8), Amasya Üniversitesi (\%42.8), Trabzon Üniversitesi (\%41.6), İstanbul Üniversitesi (\%41.6), Aksaray Üniversitesi (\%40), Ahi Evran Üniversitesi (37.5), Akdeniz Üniversitesi (\%37.5), Cumhuriyet Üniversitesi (\%33.3), Balıkesir Üniversitesi (\%33.3), Osmangazi Üniversitesi (\%33.3), Kocatepe Üniversitesi (\%30), 
Fırat Üniversitesi (\%30), Uşak Üniversitesi (\%30), Sıtkı Koçman Üniversitesi (\%28.5), Yüzüncü Y1l Üniversitesi (\%28.5), Ondokuz Mayıs Üniversitesi (\%28.5), Ankara Üniversitesi (\%25), Dicle Üniversitesi (\%25), Giresun Üniversitesi (\%25), Erciyes Üniversitesi (\%25), Mersin Üniversitesi (\%25), Binali Yıldırım Üniversitesi (\%23), Dokuz Eylül Üniversitesi (\%22.2), Mehmet Akif Ersoy Üniversitesi (\%16.6), Ege Üniversitesi (\%16.6), İbrahim Çeçen Üniversitesi (\%16.6), Sinop Üniversitesi (\%14.2) ve Uludağ Üniversitesi (\%9) de C grubunda olan üniversitelerdir.

Son olarak D grubu ise SBEABD'nda uzmanlık alanı SBE olan öğretim elemanı olmayan üniversitelerdir. Bunlar; Onsekiz Mart Üniversitesi (\%0), Kocaeli Üniversitesi (\%0), Trakya Üniversitesi (\%0) ve Celal Bayar Üniversiteleridir (\%0). Tablo 4 'de Türkiye'deki üniversitelerin SBEABD'na kayıtlı öğrenci sayısı ve öğretim elemanı başına düşen öğrenci sayıları verilmiştir.

Tablo 4 incelendiğinde; devlet üniversiteleri SBEABD'na kayıtlı öğrenci sayısı ve öğretim elemanı başına düşen öğrenci oranı verilmiştir. Bu verilere göre; SBEABD olup kayıtlı öğrenci sayıları 201 - 400 arası olan devlet üniversitelerinin çoğunlukta olduğu görülmektedir. En az kayıtlı öğrenci sayısı bulunan Sütçü İmam Üniversitesidir (97). Buna göre; bu üniversitede SBEABD yeni açılmış olup, birkaç yıldır öğrenci kaydı yapıldığ anlaşılmaktadır. En fazla kayıtlı öğrencisi bulunan da Pamukkale Üniversitesidir (419). Öğrenci Seçme ve Yerleştirme Merkezinin (ÖSYM) 2015, 2016, 2017 ve 2018 Ağustos ayı verilerine göre Türkiye'de devlet üniversitelerinde SBEABD lisans programına kayıtlı öğrenci sayısı 17.076'dır. Öğretim elemanı başına düşen kayıtlı öğrenci sayısı incelendiğinde; 15.1 ile Muş Alparslan Üniversitesi en az orana sahip, 99.7 ile Siirt Üniversitesi de en fazla orana sahip üniversite olarak görülmektedir. Bu oran SBEABD'nda görev yapan öğretim elemanı ve kayıtlı öğrenci sayısına göre değişmektedir. 
Tablo 4. Türkiye'deki Devlet Üniversitelerinin SBEABD'na Kayıtlı Öğrenci Sayısı ve Öğretim Elemanı Başına Düsşen Öğrenci Sayısı (2019)³

\begin{tabular}{|c|c|c|c|c|c|}
\hline Üniversite & K.Ö.S. ${ }^{4}$ & $\begin{array}{l}\text { Ö.E.D } \\
\text {.Ö.S. }{ }^{5}\end{array}$ & Üniversite & K.Ö.S. & $\begin{array}{l}\text { Ö.E.D } \\
\text {.Ö.S. }\end{array}$ \\
\hline Ahi Evran Üniversitesi & 358 & 44.7 & Atatürk Üniversitesi & 387 & 29.7 \\
\hline Ordu Üniversitesi & - & - & 7 Aralık Üniversitesi & 200 & 33.3 \\
\hline Ankara Üniversitesi & 279 & 34.8 & Uşak Üniversitesi & 276 & 27.6 \\
\hline Gazi Üniversitesi & 396 & 28.2 & $\begin{array}{l}\text { Gaziantep Ün. (Ni- } \\
\text { zip) }\end{array}$ & 195 & 65 \\
\hline Necmettin Erbakan Üni. & 393 & 39.3 & Uludağ Üniversitesi & 248 & 22.5 \\
\hline Süleyman Demirel Üni. & 131 & 21.8 & Bayburt Üniversitesi & 128 & 21.3 \\
\hline Çukurova Üniversitesi & 255 & 51 & Erciyes Üniversitesi & 331 & 82.7 \\
\hline Dicle Üniversitesi & 309 & 38.6 & Yüzüncü Yıl Üni. & 245 & 35 \\
\hline Bartın Üniversitesi & 224 & 32 & Mersin Üniversitesi & - & - \\
\hline Onsekiz Mart Üni. & 220 & 55 & Mustafa Kemal Üni. & - & - \\
\hline Anadolu Üniversitesi & 269 & 20.6 & M. Akif Ersoy Üni. & 266 & 44.3 \\
\hline R. T. Erdoğan Ün. & 262 & 32.7 & Kocaeli Üniversitesi & - & - \\
\hline Balıkesir Üniversitesi & 270 & 30 & A. Keykubat Üni. & - & - \\
\hline Sütçü İmam Üni. & 97 & 24.2 & Dumlupınar Üni. & 330 & 36.6 \\
\hline Gaziosmanpaşa Üni. & 284 & 40.5 & Pamukkale Üni. & 419 & 32.2 \\
\hline Amasya Üniversitesi & 272 & 19.4 & Ege Üniversitesi & 277 & 46.1 \\
\hline Osmangazi Üniversitesi & - & - & İbrahim Çeçen Üni. & 316 & 52.6 \\
\hline Giresun Üniversitesi & 355 & 29.5 & Kastamonu Üni. & 377 & 34.2 \\
\hline Akdeniz Üniversitesi & 382 & 47.7 & Ö. Halisdemir Üni. & 387 & 35.1 \\
\hline İnönü Üniversitesi & 295 & 59 & Adıyaman Üni. & 268 & 44.6 \\
\hline Kırıkkale Üniversitesi & 245 & 61.2 & Trakya Üniversitesi & 240 & 40 \\
\hline Hacı Bektaş Veli Üni. & 169 & 28.1 & Bozok Üniversitesi & 112 & 18.6 \\
\hline Alparslan Üniversitesi & 197 & 15.1 & Ondokuz Mayıs Üni. & 310 & 44.2 \\
\hline Dokuz Eylül Üni. & 404 & 44.8 & Kafkas Üniversitesi & 282 & 40.2 \\
\hline Binali Yıldırım Üni. & 331 & 25.4 & Çoruh Üniversitesi & 195 & 32.5 \\
\hline Trabzon Üniversitesi & 402 & 33.5 & Siirt Üniversitesi & 399 & 99.7 \\
\hline Sakarya Üniversitesi & 268 & 38.2 & Cumhuriyet Üni. & 393 & 43.6 \\
\hline Adnan Menderes Üni. & 265 & 33.1 & Celal Bayar Üni. & 308 & 38.5 \\
\hline Fırat Üniversitesi & 281 & 28.1 & İstanbul Ün. C.Paşa & 275 & 22.9 \\
\hline Marmara Üniversitesi & 374 & 46.7 & Kocatepe Üni. & 370 & 37 \\
\hline Sıtkı Koçman Üni. & 311 & 22.2 & Bülent Ecevit Üni. & 236 & 26.2 \\
\hline Yıldız Teknik Üni. & 225 & 25 & Aksaray Üniversitesi & 243 & 24.3 \\
\hline Harran Üniversitesi & - & - & Sinop Üniversitesi & 229 & 32.7 \\
\hline Abant İzzet Baysal Üni. & 311 & 38.8 & & & \\
\hline Toplam & & & & 17.076 & 100 \\
\hline
\end{tabular}

\footnotetext{
${ }^{3}$ Tablo 4'deki bilgiler ÖSYM'den 2015, 2016, 2017 ve 2018 Ağustos ayında alınan verilerden derlenmiştir (YÖK, 2018).

${ }^{4}$ Kayıtlı ögrenci sayısı

5 Ögrretim elemanına düşen öğrenci sayısı
} 


\section{Sonuç, Tartışma ve Öneri}

$\mathrm{Bu}$ araştırmanın genel amacl; Türkiye'deki devlet üniversiteleri eğitim fakültelerinde bulunan SBEABD'nın lisans ve lisansüstü eğitim durumunu, bu programlarda görev yapan öğretim elemanlarının sayı, cinsiyet, kadro unvanı, uzmanlık alanlarını ve kayıt öğrenci sayısı ile öğretim elemanına düşen öğrenci oranını incelemektir. Toplanan verilerin ve yapılan veri çözümlemelerin sonucunda; Türkiye'deki 129 devlet üniversitesinin eğitim fakültelerinin 67 'sinde SBEABD olduğu belirlenmiştir. Bu 67 devlet üniversitesinin 60'inda lisans öğrencileri öğrenim görmektedir. Diğer 7 üniversitede ise anabilim dalı olmakla birlikte lisans öğrencisi bulunmamaktadır. SBEABD olan 67 üniversitenin 50'sinde yüksek lisans eğitimi, 19'unda da doktora eğitimi programı bulunmaktadır. Baysan, Ercan ve Öztürk (2011), 1997 yılında Sosyal Bilgiler Öğretmenliği programı olan 3 üniversitenin, 2007 yılında ise 43 üniversitenin olduğunu belirtmiştir. Kaymakçı ve Öztürk'ün (2011) yaptığı araştırmada, Türkiye'de 44 üniversitede SBEABD lisans programı, bu üniversitelerin 23'ünde yüksek lisans programı ve 4 doktora programı olduğunu belirtmişlerdir. İnan, (2018) 2014 itibariyle Türkiye ve Kıbrıs'taki üniversitelerinde 61 "Sosyal Bilgiler Öğretmenliği" programının olduğunu ifade etmiştir. Yine Tokcan ve Tilki (2018) de yaptıkları çalışmada SBEABD lisans programı olan üniversite sayısının 59 olduğunu belirtmişlerdir. Verilen eğitim düzeyi yükseldikçe açık olan lisansüstü SBEABD azalmaktadır. Ankara' da iki adet ve İstanbul'da üç adet yüksek lisans programı bulunmaktadır. Doktora programı ise yalnız İstanbul'da iki farklı üniversitede bulunmaktadir.

Türkiye'de devlet üniversitelerinde SBEABD'nda en fazla öğretim elemanının görev yaptığı üniversitelere; Sıtkı Koçman Üniversitesi, Amasya Üniversitesi, Gazi Üniversitesi, Anadolu Üniversitesi, Atatürk Üniversitesi, Pamukkale Üniversitesi, Giresun Üniversitesi, Erzincan Üniversitesi ve Alparslan Üniversitesi örnek verilebilir. En az öğretim elemanının görev yaptığı üniversitelere de Kocaeli Üniversitesi, Alaattin Keykubat Üniversitesi, Ordu Üniversitesi, Osmangazi Üniversitesi, Gaziantep Üniversitesi (Nizip Eğitim), Harran Üniversitesi vb. örnek verilebilir.

Türkiye'de SBEABD'nda toplam 523 öğretim elemanı görev yapmaktadır. 2014 yılında bu sayı 416'dır ve dağılımı şu şekildedir: 34 Profesör; 
59 Doçent; 168 Yardımcı Doçent; 45 Öğretim Görevlisi; 2 Okutman; 108 Araştırma Görevlisi (İnan, 2018:14). Öğretim elemanlarının kadro unvanlarl; Profesör Doktor, Doçent Doktor, Doktor Öğretim Üyesi, Araştırma Görevlisi Doktor, Araştırma Görevlisi, Öğretim Görevlisi Doktor, Öğretim Görevlisi ve Okutman şeklindedir. Bu kadro unvanlarının içerisinde en fazla oran Doktor Öğretim Üyesi, en az oran Okutman kadro unvanına aittir. Erkek öğretim elemanlarının oranı kadınlardan daha fazladır. Bu durum sadece SBEABD için geçerli olmamakla birlikte YÖK'ün güncel verilerine göre de Türkiye'deki devlet üniversitelerinde görev yapan öğretim elemanlarının çoğunluğunun erkek olduğu belirtilmektedir (YÖK İstatistik, 2019). Öğretim elemanlarının uzmanlık alanları çeşitlilik göstermektedir. Buna göre; SBE, Tarih, Coğrafya, Coğrafya Eğitimi, Tarih Eğitimi, Ĕ̆itim Bilimleri vb. alanlarda uzmanlaşmışlardır. Ancak farklı uzmanlık alanları da mevuttur. Bunlar; Edebiyat, Gazetecilik, Felsefe, Bilgisayar ve Öğretim Teknolojileri, Halkla İlişkiler, Sosyoloji ve Psikolojidir. SBEABD'nda Sosyal Bilgiler/Sosyal Bilimler ile doğrudan ilgili alanlar olmasının yanında doğrudan ilgisi olmayan uzmanlık alanlarına sahip öğretim elemanlarının da görev yaptığı görülmektedir. Uzmanlık alanı SBE olan en fazla kadro unvanı Doktor Öğretim Üyesi'dir. Bunu Araştırma Görevlisi ve Doçent Doktor kadro unvanı takip etmektedir. SBE uzmanlık alanına sahip Profesör Doktor'un oldukça az olduğu görülmektedir. Bunun sebebinin SBEABD lisans programının ilk mezunlarını 2002 yılında vermesi olarak düşünülebilir. Ayrıca Doçent Doktor sayısının da Türkiye'deki SBEABD lisans programlarının sayısına nazaran yetersiz olduğu görülmektedir. Bu nedenle SBEABD doktora programı sayısının az olduğu söylenebilir. YÖK'ün doktora programı açma kriterleri de bu durumun sebeplerinden biridir. Uzmanlık alanı SBE olan öğretim elemanı oranı en fazla olan; Ordu Üniversitesi, Sütçü İmam Üniversitesi, Bartın Üniversitesi, Süleyman Demirel Üniversitesi, Gaziosmanpaşa ve Sakarya Üniversiteleri'dir. Onsekiz Mart Üniversitesi, Kocaeli Üniversitesi, Trakya Üniversitesi ve Celal Bayar Üniversitesinde uzmanlık alanı SBE olan öğretim elemanı bulunmamaktadır (Bkz. Tablo 3). Çoban (2014) bu konu ile ilgili; son 10 yılda alan eğitimi üzerine gerçekleştirilen lisansüstü çalışmalar ve eğitim fakültelerindeki yeni kuşak öğretim üyelerinin büyük çoğunluğunun lisansüstü derecelerini 
alan eğitiminden almış olmaları alan eğitimi adına sevindirici olduğunu ifade etmiştir.

SBEABD olup kayıtlı öğrenci sayıları 201 - 400 arası olan devlet üniversiteleri çoğunluktadır. En az kayıtlı öğrenci sayısı bulunan Sütçü İmam Üniversitesidir (97). Buna göre; bu üniversitede SBEABD yeni açılmış olup, birkaç yıldır öğrenci kaydı yapıldığı anlaşılmaktadır. En fazla kayıtlı öğrencisi bulunan da Pamukkale Üniversitesidir (419). ÖSYM'nin 2015, 2016, 2017 ve 2018 Ağustos ayı verilerine göre Türkiye'de devlet üniversitelerinde SBEABD lisans programına kayıtlı öğrenci sayısı 17.076'dır (YÖK Atlas, 2019). Öğretim elemanı başına düşen kayıtlı öğrenci sayısı 15.1 ile Muş Alparslan Üniversitesi en az orana sahip, 99.7 ile Siirt Üniversitesi de en fazla orana sahip üniversite olarak görülmektedir. Bu oran SBEABD'nda görev yapan öğretim elemanı ve kayıtlı öğrenci sayısına göre değişmektedir. Arslan da (2011) yaptığı çalışmada; öğretim elemanına düşen öğrenci sayısında üniversiteler arasında dengesizliklerin olduğunu belirtmiştir. İnan da (2018) üniversite başına 65 öğrenci düştügünü belirtmiştir. Bu doğrultuda araştırmadan elde edilen sonuçlara dayalı olarak;

$\mathrm{Bu}$ araştırma, SBEABD üzerine yapılmıştır. Farklı ana bilim dalı ile ilgili araştırmalar yapılması,

Üniversitelerin öğretim elemanı sayısı kısa zaman içerisinde değişebileceğinden, bu tür araştırmaların daha sık yapılması,

Türkiye'deki üniversitelerin Sınıf Eğitimi Ana Bilim Dalında da uzmanlık alanı SBE olan öğretim elemanları görev yapmaktadır. Farklı bir çalışmada bu durum gözetilebilir,

Bu tür araştırmalar; lisans ve lisansüstü eğitim düşünen öğrenciler için anabilim dalının durumu ve genel anlamda SBE alanı ile ilgili rehber bilgi niteliği taşıyabilir,

Üniversitelerin SBEABD öğretim elemanları ve yöneticileri, personel planlaması hususunda bu araştırmadan yararlanılması,

YÖK ve üniversiteler lisans ve lisansüstü eğitim yapılanması hususunda bu araştırmadaki verilerden yararlanılması,

Sadece SBE alanında değil üniversitelerde kadın öğretim elemanı oranının artırılması hususunda çalışmalar yapılması,

Araştırma verilerinden anlaşıldığı üzere, bazı üniversitelerde uzmanlık alanı SBE olan öğretim elemanı varken bazı üniversitelerde hiç 
mevcut değildir. Bu bağlamda, uzmanlık alanı SBE olan öğretim elemanlarının üniversitelere uygun bir şekilde dağılımının sağlanması hususunda çalışmalar yürütülmesi,

SBEABD'nda kayıtlı öğrenci sayısı ve mezun olarak atama bekleyen öğretmen sayısı düşünüldügünde, gelecek yıllarda Sosyal Bilgiler Öğretmenliği lisans programına öğrenci alım oranının düşürülmesi ile ilgili çalışmalar yapılabilir. 2023 Eğitim Vizyonu çerçevesinde öğretmen niceliğinden ziyade öğretmenin niteliği üzerine çalışılması,

SBE alanında lisans programı ve öğrenci sayısının azaltılarak, yüksek lisans ve doktora program ve öğrenci sayısının artırılması konusunda çalışmalar yapılması,

2018 norm kadro yönetmeliği gereği birçok üniversite norm fazlası durumda olduğu verilerden anlaşılmaktadır. Bu durum ise, lisansüstü eğitim düşünen ve hali hazırda lisansüstü eğitim gören öğrenciler için umutsuzluk oluşturabilir. Diğer yandan öğretim elemanlarının zaman içerisinde yer değiştirme talepleri olumsuz durumlara yol açabilir. Araştırma sonuçlarına dayalı olarak, hem akademiyi düşünen öğrenciler için hem de görevde olan öğretim elemanları için bilimin geleceği oluşturma/planlama hususunda norm kadro yönetmeliğinde kolaylaştırıcı önlemler alınması yönünde önerilerde bulunulmaktadır. 
EXTENDED ABSTRACT

\title{
The Status of Higher Education in Social Studies Education in Turkey
}

\author{
Erhan Yaylak
}

Ordu University

The history of raising social studies teachers in our country is directly proportional to the fact that this course is included in the Turkish education system. In other words, it is not possible to talk about social studies teacher training programs before 1968. Because the single-disciplinary approach that dominated this period made it necessary for the teachers of history and geography to teach social studies subjects. In this context, the process which started with teacher training in the history-geography department of Gazi Middle School and Education Institute during the Republic period, continued in the social studies section of the literature section connected to three-year educational institutes since the 1967-1968 school year (Altunya, 2006; Günay, 2017; Öztürk, 2005; Dursunoglu, 2003). From 1978 to 1979 academic year, the education institutes were transformed into four-year higher education schools, and the social studies department was removed, and history-geography and geography-history sections were established (Ercan, 2009). Since 1982, the conversion of high teacher schools into education faculties and transferring them to universities did not cause any change in the process of raising social studies teachers and the teachers who will teach the social sciences subject area continued to be trained in history and geography teaching departments (YÖK, Akt. Kaymakc1, 2012. p.46).

The Council of Higher Education initiated the restructuring process in the faculties of education with the decision dated 04.11.1997 and numbered 97.39.2761, and in this context, the implementation of the rearranged teacher training programs has been implemented since the academic year of 1998-1999 (Çoban, 2010. p.30). In particular, the transition to eight years of compulsory and non-formal education and social studies from a holistic point of view from the 4 th grade to the 7 th grade as a course 
that continues to be re-taught in the faculties of education in the elementary school of social studies teaching programs has been opened (Kaymakç1, 2012. p.46). In the academic year 1997-1998, students were only enrolled in the Social Studies Teaching Program of the Faculty of Education of Celal Bayar, Selcuk, and Gazi Universities. In the same year, the total number of students was 190. In the 1998-1999 academic year, the number of faculties of education that received students in the Social Studies Teaching Program reached 28, and the total student quota reached 2950 (Özav, 2001. p.166). When the social studies teaching program was first opened, the need of the department was provided by the faculties of science and literature. Because there was no teaching staff trained in the field of social studies education. In 2002, she gave the first graduates of social studies teaching program and accepted her first graduate students this year. Students who graduated from social studies teaching program in 2002 and the following years and continued their graduate studies started to take part in social studies education departments as lecturers. This research aims to determine the current status of the Department of Social Studies Education; education-teaching structure, to examine the structure of the instructor and to reveal a result from the data obtained. For this purpose, the following questions were searched;

1. Which university located in the Department of Social Studies Education in Turkey?

2. Which has a Social Studies Education postgraduate program in universities in Turkey?

3. Which has a Social Studies Education doctorate program in universities in Turkey?

4. The Department of Social Studies Education in Turkey which are also non-university undergraduate students?

5. What is the number of teaching staff in Social Studies Education Department?

6. What is the distribution of the number of teaching staff by gender and staff title?

7. What are the fields of expertise of the teaching staff working in the Department of Social Studies Education? 
8. What is the distribution of the fields of expertise of the academic staff working in the department of social studies according to gender and staff title?

9. What is the number of faculty members working in Social Studies Education departments of universities in Turkey? What is the ratio of the number of faculty members with social studies education and the ratio of the university?

10. What is the number of students enrolled in the Department of Social Studies Education in Turkey? What is the ratio of students per instructor?

\section{Method}

In this study, the case study method which is one of the qualitative research methods is used. The case study is an in-depth description and examination of a limited system (Merriam, 2013. pp.40; Glesne, 2014. p.30). The situation in the case study; an individual, group, organization, status or anything of interest (Rabson, 2017. p.159). The case study can be used in both quantitative and qualitative research. The main feature of the qualitative case study is to investigate the depth of one or more situations. In other words, factors related to a situation (environment, individuals, events, processes, etc.) are investigated with a holistic approach, and they are focused on how they affect the situation and how they are affected by the situation (Yıldırım \& Şimşek, 2018. p.83).

\section{Results}

As a result of the research; 67 of 129 public universities in the social sciences faculties of education in Turkey was determined that training program. 60 of these 67 state universities have undergraduate students. In the other seven universities, there is no department. 50 of 67 universities, which are social studies education program, have master's degree education and 19 of them have Ph.D. programs. Kaymakçı and Öztürk (2011) in his research, social studies education degree program in 44 universities in Turkey, stated that these universities have graduate programs and four 
doctoral programs in 23. Tokcan and Tilki (2018) in their study of the number of universities in the social studies education department is 59 said. The higher the level of education given, the lower the graduate program of social studies education. There are two graduate programs in Ankara and three in Istanbul. The Ph.D. program is only available in two different universities in Istanbul. In Turkey, the state department of education in social studies at the university, where served most of lecturers to universities; Sıtkı Koçman University, Amasya University, Gazi University, Anadolu University, Atatürk University, Pamukkale University, Giresun University, Erzincan University, and Alparslan University. Kocaeli University, Alaattin Keykubat University, Ordu University, Osmangazi University, Gaziantep University (Nizip Education), Harran University, etc. example.

A total of 523 teaching staff are employed in the Department of Social Studies Education. In 2014, this number was 416, and its distribution is as follows: 34 Professor; 59 Associate Professors; 168 Assistant Professors; 45 Lecturer; 2 Instructor; 108 Research Assistants (İnan, 2018. pp.14). Staff titles of teaching staff; Professor Doctor, Associate Professor Doctor, Assistant Professor Doktor, Research Assistant Doctor, Research Assistant, Instructor Doctor, and Instructor. The highest proportion of these staff titles is Assistant Professor Doctor, and the minimum rate belongs to Lecturer staff title. The proportion of male teaching staff is higher than women. In this case, it is stated that only Social Studies Education majors to be applicable to dive with HEC according to the latest data of the teaching staff who work in state universities in Turkey, the majority were male (Higher Education Statistics, 2019). The fields of expertise of the teaching staff vary.

According to this; Social Studies Education, History, Geography, Geography Education, History Education, Educational Sciences, etc. specialize in areas. However, there are different fields of expertise. These; Literature, Journalism, Philosophy, Computer and Instructional Technologies, Public Relations, Sociology, and Psychology. In the Social Studies Education Department, there are areas directly related to social studies as well as the teaching staff who have expertise areas which are not directly related. The field of specialization is Social Studies Education, and the maximum number of staff is Assistant Professor Doctor. This is followed by the title of Research Assis- 
tant and Associate Professor. It is seen that Professor Doctor who has a specialization in Social Studies Education is quite a few. The reason for this is that Social Studies Education can be considered as the first graduates of the undergraduate program in 2002. Also, the number of doctors in Social Studies Education professors in Turkey appears to be insufficient compared to the number of education degree program. Therefore, it can be said that the number of Ph.D. programs in Social Studies Education is low. The criteria of the Council of Higher Education (YÖK) to open a doctoral program are one of the reasons. The area of specialization is the highest proportion of teaching staff with Social Studies Education; Ordu University, Sütçü İmam University, Bartın University, Süleyman Demirel University, Gaziosmanpaşa and Sakarya Universities. Onsekiz Mart University, Kocaeli University, Trakya University, and Celal Bayar University do not have any teaching staff with specialization in social studies (See Table 3). Çoban (2014) about this subject; In the last 10 years, the postgraduate studies on field education and the fact that the majority of the new generation of faculty members in the faculties of education have received their master's degree from the field education stated that they are pleased in the name of the field education.

The number of students enrolled in the Social Studies Education Department is between 201-400, and the state universities are the majority. The least number of registered students is Sütçü İmam University (97). According to this; The department of social studies education was opened in this university, and it is understood that the student enrollment was made for a few years. Pamukkale University is the most registered student (419). Student Selection and Placement Center in 2015, 2016 and 2017 and the month of August 2018, according to the number of students enrolled in Social Studies Education degree programs at state universities in Turkey 17.076. The number of registered students per lecturer is 15.1, and Muş Alparslan University has the lowest rate, and 99.7 and Siirt University has the highest rate. This rate varies according to the number of faculty members and registered students in the Department of Social Studies Education. Arslan (2011) in his study; stated that there are imbalances between the universities in the number of students. Inan (2018) stated that 65 students fell per university. Based on the results obtained from the research in this direction; 
This research was conducted on social studies education. Researching different departments, Since the number of the academic staff of the universities may change in a short period, In the department of classroom education of universities, academic staff with specialization in the field of social studies are employed. This situation can be observed in a different study, Such research; be able to guide the status of the department for the students considering undergraduate and graduate education and social studies education in general,

Teaching staff and managers of social studies education department of universities, taking advantage of this research about personnel planning, YÖK and universities take advantage of the data in this study regarding the structuring of undergraduate and graduate education, Studies in the field of increasing the ratio of female teaching staff in universities, not only in the area of social studies education, As can be seen from the research data, some universities do not exist in some universities while there is an instructor who has social studies education. In this context, conducting studies to ensure the proper distribution of faculty members with specialization in social studies education to universities,

Considering the number of students enrolled in the Department of Social Studies Education and the number of teachers waiting to be appointed as graduates, studies on lowering the rate of recruitment to the social studies teaching the program in the next years can be done. Training on the quality of teachers rather than teachers in the framework of 2023 Education Vision,

Studies on increasing the number of undergraduate and graduate programs in the field of social studies education and increasing the number of graduate and doctorate programs and students,

According to 2018 norm staff regulations, it is understood from the data that there are many university norms. This may create hopelessness for postgraduate students who are currently studying for postgraduate studies. On the other hand, displacement demands of instructors may lead to negative situations. In this context, it is suggested that facilitators should be taken in the norm staff regulation to create a future for science for the students who think the academy and for the teaching staff in charge. 


\section{Kaynakça / References}

Abazoğlu, İ., Yıldırım, O. ve Yıldızhan, Y. (2016). Geçmişten günümüze Türk eğitim sisteminde öğretmen yetiştirme. Uluslararası Türk Eğitim Bilimleri Dergisi, 4(6), 143-160. http://dergipark.gov.tr/download/article-file/405320. (Erişim Tarihi: 18.03.2019).

Aktaş, M., C. (2014). Nitel veri toplama araçları. Mustafa Metin (Ed.), Kuramdan Uygulamaya Eğitimde Bilimsel Araştırma Yöntemleri içinde (s. 337-371). Ankara: Pegem Akademi.

Altunya, N. (2006). Gazi Ĕğitim Enstitüsü: Gazi Orta Öğretmen Okulu ve Eğitim Enstitüsü (1926-1980). Ankara: Gazi Üniversitesi Yayınları.

Arslan, Y. (2011). Eğitim fakültelerinin öğrenci sayısı ve öğretim üyesi sayısı değişkenlerine göre incelenmesi. 20.Ulusal Eğitim Bilimleri Kurultayı Bildirileri. Ankara: Pegem Akademi Yayıncılık.

Baysan, S., Ercan, B. ve Öztürk, A. (2011). Türkiye'de öğretmen yetiştirmede istihdam sorunu: Sosyal Bilgiler öğretmenliği örneği. Muğla Üniversitesi Sosyal Bilimler Enstitüsü Dergisi, 26, 131-154. http://dergipark.gov.tr/download/article-file/217518. (Erişim Tarihi: 31.03.2019).

Best, J., W. and Kahn, J. V. (2017). Eğitimde araştırma yöntemleri. Konya: Eğitim Yayınevi.

Çoban, A. (2010). Sosyal Bilgiler öğretmenliği lisans programı: Betimsel bir karşılaştırma. Gaziosmanpaşa Üniversitesi Sosyal Bilimler Araştırmaları Dergisi, 5(2), 27-46. doi: 10.19129/sbad.168.

Çoban, Ü. G. (2014). Türkiye'de öğretmen yetiştirme. Aydınlık Bir Türkiye İçin Eğitim Reformu (Ed. Kemal Kocabaş). İzmir: Yeni Kuşak Köy Enstitüleri Derneği Yayınları.

Dursunoğlu, H. (2003). Cumhuriyet döneminde ilköğretime öğretmen yetiştirmenin tarihi Gelişimi. Milli Ĕ̆gitim Dergisi, 160, xxx-xxx. https://dhgm.meb.gov.tr/yayimlar/dergiler/Milli EgitimDergisi/160/dursunoglu.htm. (Erişim Tarihi: 26.02.2019).

Ercan, B. (2009). Türkiye'de ilköğretim II. kademeye Sosyal Bilgiler öğretmeni yetiştirme sistemleri (1923- 2008). Yayınlanmamış Yüksek Lisans Tezi. Adnan Menderes Üniversitesi Sosyal Bilimler Enstitüsü,Aydin. 
Erdoğan, İ. (2014). Günümüz Türkiye'sinde öğretmen yetiştirme: Mevcut durum ve çözüm önerileri. Cumhuriyet Dönemi Eğitim Politikaları Sempozyumu. Ankara: Atatürk Araştırma Merkezi Yayınları.

Glesne, C. (2014). Nitel araştırmaya giriş. Ankara: Anı Yayıncılık.

Günay, N. (2017). Gazi Terbiye Enstitüsü'nden Gazi Üniversitesi'ne: Türk eğitim ve kültür tarihinde Gazi. Ankara: Gazi Eğitim Fakültesi Yayınları.

Güven, İ. (2010). Türk eğitim tarihi. Ankara: Naturel Yayınları.

İnan, S. (Ed.) (2018). Sosyal Bilgiler eğitimine giriş. Ankara: Anı Yayıncılık.

Karadağ, E. ve Yücel, C. (2018). Devlet üniversiteleri ve fakülteleri stralaması [DÜS] 2018. Üniversite Araştırmaları Laboratuvarı Yayınları. doi:10.13140/RG.2.2.17310.84804.

Karasar, N. (2012). Bilimsel araştırma yöntemi. Ankara: Nobel Yayın Dağıtım.

Kaymakçı, S. (2012). Sosyal Bilgiler öğretmenliği lisans programlarının içerik değerlendirmesi. Uluslararası Sosyal Bilimler Eğitimi DergisiUSBED, 2(1), 45-61. http://dergipark.gov.tr/download/articlefile/261761. (Erişim Tarihi: 11.02.2019).

Kaymakçı, S. ve Öztürk, T. (2011). The panorama of social studies education in Turkey. E-Journal of New World Sciences Academy: Education Sciences, 6(2), 1852-1867. http://dergipark.gov.tr/download/articlefile/185598. (Erişim Tarihi: 30.03.2019).

Merriam, S. B. (2013). Nitel araştırma: Desen ve uygulama için bir rehber. Ankara: Nobel Yayıncilı.

Özav, L. (2001). Sosyal bilgiler öğretmenliği lisans programı üzerine düşünceler. Afyon Kocatepe Üniversitesi Sosyal Bilimler Dergisi, 3(1), 165-177. http://sbd.aku.edu.tr/III1/14.pdf. (Erişim Tarihi: 11.02.2019).

Özer, M. (2011). Türkiye'de yükseköğretimde büyüme ve öğretim üyesi arzı. Yükseköğretim ve Bilim Dergisi, 1(1), 23-26. DOI: 10.5961/jhes.2011.002.

Öztürk, C. (2005). Türkiye'de dünden bugüne öğretmen yetiştiren kurumlar. İstanbul: MEB Yayınları.

Rabson, C. (2017). Bilimsel araştırma yöntemleri: Gerçek dünya araştırması. Ankara: Anı Yayıncilik. 


\section{Kaynakça Bilgisi / Citation Information}

Yaylak, E.(2019). Türkiye'de sosyal bilgiler eğitiminin yükseköğretimdeki durumu. OPUS-Uluslararası Toplum Araştırmaları Dergisi, 11(18), 800-838. DOI: $10.26466 /$ opus.545800. 